\title{
Sniffing Out Urinary Tract Infection-Diagnosis Based on Volatile Organic Compounds and Smell Profile
}

\author{
Valentin-Mihai Dospinescu ${ }^{1} \mathbb{D}$, Akira Tiele ${ }^{2} \mathbb{D}$ and James A. Covington ${ }^{2, *} \mathbb{D}$ \\ 1 Warwick Medical School, University of Warwick, Coventry CV4 7AL, UK; V.Dospinescu@warwick.ac.uk \\ 2 School of Engineering, University of Warwick, Coventry CV4 7AL, UK; F-A.Tiele@warwick.ac.uk \\ * Correspondence: j.a.covington@warwick.ac.uk; Tel.: +44-(0)-24-765-74494
}

Received: 24 June 2020; Accepted: 20 July 2020; Published: 23 July 2020

\begin{abstract}
Current available methods for the clinical diagnosis of urinary tract infection (UTI) rely on a urine dipstick test or culturing of pathogens. The dipstick test is rapid (available in 1-2 min), but has a low positive predictive value, while culturing is time-consuming and delays diagnosis (24-72 $\mathrm{h}$ between sample collection and pathogen identification). Due to this delay, broad-spectrum antibiotics are often prescribed immediately. The over-prescription of antibiotics should be limited, in order to prevent the development of antimicrobial resistance. As a result, there is a growing need for alternative diagnostic tools. This paper reviews applications of chemical-analysis instruments, such as gas chromatography-mass spectrometry (GC-MS), selected ion flow tube mass spectrometry (SIFT-MS), ion mobility spectrometry (IMS), field asymmetric ion mobility spectrometry (FAIMS) and electronic noses (eNoses) used for the diagnosis of UTI. These methods analyse volatile organic compounds (VOCs) that emanate from the headspace of collected urine samples to identify the bacterial pathogen and even determine the causative agent's resistance to different antibiotics. There is great potential for these technologies to gain wide-spread and routine use in clinical settings, since the analysis can be automated, and test results can be available within minutes after sample collection. This could significantly reduce the necessity to prescribe broad-spectrum antibiotics and allow the faster and more effective use of narrow-spectrum antibiotics.
\end{abstract}

Keywords: urinary tract infection (UTI); electronic nose (eNose); volatile organic compound (VOC); ion mobility spectrometry (IMS); gas chromatography-mass spectrometry (GC-MS); pattern recognition; metabolite detection

\section{Introduction}

A urinary tract infection (UTI) is a microbial condition that can affect any part of the urinary system. UTI is one of the most common bacterial infections with 150 million cases per year worldwide [1]. Adult women are 30 times more likely than men to develop a UTI [2]. Moreover, it is estimated that $50-60 \%$ of women will experience at least one episode of UTI during their lifetime [1] with the prevalence increasing with age ( $20 \%$ in women over 65 and overall population prevalence of $11 \%)[3,4]$. UTI is a major global health burden, causing great distress as it is very uncomfortable and impedes the patient's ability to conduct day-to-day activities, such as work $[3,5,6]$.

Current diagnostic methods rely heavily on a urine dipstick test, which offers a fast result (available in 1-2 $\mathrm{min}$ ) but has a low positive predictive value [7]. The accepted alternative method involves culturing of the pathogens, which is more accurate and can inform clinicians on the type of bacteria present. This is time-consuming and delays diagnosis (24-72 $\mathrm{h}$ between sample collection and pathogen identification) [4]. Broad-spectrum antibiotics are therefore often prescribed immediately. However, due to the delay, this practice is fuelling antimicrobial resistance. As a result, there is a growing need 
for alternative diagnostic tools. Recent advances in chemical-analysis technologies suggest that it might be possible to 'sniff out' medical conditions, including bacterial infections, by analysing volatile organic compounds (VOCs) emanating from the body and its waste.

The use of smell is possibly one of the earliest forms of medical diagnosis. Both ancient Chinese and Greek physicians already recognised its diagnostic potential [8]. The father of modern medicine, Hippocrates, used to put sputum samples on hot coals to generate an odour, then, based on the smell, apply different treatments $[9,10]$. The basic concept of using odours to distinguish between disease states has been supported by studies utilising the olfactory abilities of well-trained canines $[10,11]$. Numerous studies have demonstrated the ability of canines to smell cancers in the bladder [12], lung [13], breast [14], prostate [15], and ovaries [16]. Despite their abilities, medical detection dogs are very expensive to train and are impractical for routine clinical use.

It is now understood that odours mainly comprise of volatile organic compounds (VOCs), which are carbon-based compounds, with high vapour pressure and low boiling points. VOCs are produced within the body as a result of metabolic processes from the host, from microbial pathogens, or resulting from a host response to pathological processes, such as infection or inflammation [17]. VOCs in urine are considered intermediate or end products of metabolic pathways [18]. These occur in relatively higher concentrations than in other medium, such as breath-which makes them easier to detect [19]. Recent studies have shown that characteristic urine VOC profiles can be linked to infectious diseases [20,21] and different types of cancers [22-24]. These studies have demonstrated the potential in utilising urine for diagnostic purposes.

The objective of this article is to review previous studies, focusing on the utility of urine headspace VOC analysis as a diagnostic tool for UTI. This review first discusses UTIs and critically evaluates the current diagnostic approach. Next, the paper reviews the analytical platforms that have been evaluated as potential diagnostic tools for UTIs and summarises their characteristics. An extensive list of VOCs associated with common UTI pathogens, either in cultures or urine samples, is then presented. Finally, the developments needed to bring this approach into clinical practice are discussed.

\section{Urinary Tract Infection}

UTI can affect any part of the urinary system-kidneys (pyelonephritis), uterus, bladder (cystitis) and urethra (urethritis). Most UTIs involve the lower urinary tract (bladder and urethra). The infection can be caused by bacteria (Gram-negative and Gram-positive), as well as fungi. Furthermore, $70 \%$ of community-acquired UTIs and $50 \%$ of hospital-associated UTI are caused by UroPathogenic Escherichia coli (UPEC) $[25,26]$.

UTIs can be classified as complicated or uncomplicated. When cystitis or pyelonephritis occurs in an otherwise healthy individual (premenopausal and non-pregnant women) and no abnormalities are present in the urinary tract, the UTI is considered uncomplicated [27]. Immunocompromised individuals, pregnant women, or patients with urinary tract abnormalities and UTI are classified as complicated [28]. Abnormalities associated with complicated UTI include obstructions (tumours of the urinary tract), instrumentation (indwelling urethral catheter) or metabolic abnormalities (renal failure) [28]. If a UTI is not treated, the infection could spread from the kidneys into the bloodstream, causing bacteraemia. If a systemic inflammatory response occurs, this could potentially be followed by septicaemia, which can be fatal $[1,29,30]$.

Even though UTI is rarely fatal, it produces high morbidity in vast numbers of patients. A patient with cystitis often presents with urinary symptoms, which include dysuria (painful urination), urinary frequency, urgency or haematuria (blood in urine) [1]. As the onset of UTI is sudden, rapid and painful, it often incapacitates the person from their normal day-to-day activities, creating a feeling of guilt and even depression [6]. Both physical and social functioning are negatively affected [3]. The direct impact of UTI on health care relates to the cost of prescriptions, hospital expenses, travel, medical visits and diagnosis-sometimes multiple urine cultures and imaging studies are required [31]. Overall, it results in lowering the patient's quality of life. 
Most commonly, UTI is initiated when a urinary pathogen from the bowel (sometimes from the vagina-inoculation during sexual activity) enters the urinary tract via the urinary meatus [27]. In uncomplicated UTI, following UPEC, the most common pathogens are: Klebsiella pneumoniae, Staphylococcus saprophyticus, Enterococcus faecalis, group B Streptococcus, Proteus mirabilis, Pseudomonas aeruginosa, Staphylococcus aureus, and Candida spp [1]. In complicated UTI, the most prevalent agents of infection after UPEC are: Enterococcus spp., K. pneumoniae, Candida spp., Staphylococcus aureus, P. mirabilis, $P$. aeruginosa, and group B Streptococcus [1].

Broad-spectrum antibiotics are generally used for treating UTIs. However, with a better understanding of the adverse impact this has on commensal bacteria present in the gut microbiome, this practice is becoming of concern to healthcare professionals [32]. Moreover, the over-prescription of broad-spectrum antibiotics could accelerate the development of antimicrobial resistance (AMR). It is estimated that, by 2050, AMR will cause 10 million deaths globally (more than cancer-8.2 million) [33]. The threat to patients is acquiring a multidrug-resistant agent, i.e., a microorganism that shows antimicrobial resistance to at least one antimicrobial drug in three or more antimicrobial categories. In recent years, the number of multidrug-resistant Gram-negative bacteria have increased and have been found to cause UTIs [34]. Furthermore, antibiotics increase inflammation in the gut, which promotes the proliferation of E. coli [35]. Since UPEC is usually found in the gastrointestinal tract, the surge in proliferation increases the risk of subsequent UTI recurrence. As a result, broad-spectrum antibiotics can be used to treat UTIs, but this also increases the risk of developing UTIs in future. UK NICE guidelines (National Institute for Health and Care Excellence) recommends the use of narrow-spectrum agents for UTIs whenever possible. This approach would be feasible if the pathogen could be rapidly identified.

\section{Current Diagnostic Methods for Urinary Tract Infection}

The diagnosis of UTI is currently based on culturing samples in a centralised clinical laboratory, which results in a delay of 24-72 h from the moment the patient provides the sample to identifying the bacteria. UTIs are usually defined by the urinary symptoms and the presence of at least $10^{4} \mathrm{CFU} / \mathrm{mL}$ in urine, though the cut-off point differs (NHS considers $10^{5} \mathrm{CFU} / \mathrm{mL}$ as positive and the threshold changes based on the presented symptoms) $[25,36]$.

In the 1980s, the urine dipstick test was introduced to provide a fast, cheap and useful test in diagnosing UTI. The dipstick test is a qualitative test, which assesses the presence of leukocyte esterase and nitrate. Leukocyte esterase is a protein made by white blood cells and acts as a biomarker for those immune cells. The presence of leukocytes in urine is indicative of a UTI. Nitrite is found in urine due to the presence of nitrate reducing bacteria. Even though the dipstick is a cheap and fast test, it does not narrow down the infection to a causative agent and may even miss some infections (e.g., non-nitrate reducing bacteria). In a meta-analysis, the overall sensitivity of the urine dipstick test for leukocyte esterase was $48-86 \%$, with a specificity of 17-93\%. For the nitrate dipstick test, the sensitivity was even lower, with values between $45 \%$ and $60 \%$, and a specificity of $85-98 \%$. Overall, when combining both tests, the sensitivity increases to $68-88 \%$ and specificity to $62-97 \%$ (one or both positive), depending on the brand, cut-off standard, and population demographic [37]. A similar study found a sensitivity of $75 \%$ and specificity of $82 \%$ [38].

A rapid point-of-care test, which can accurately identify the pathogen, would have a positive impact on UTI treatment, since the most effective course of antibiotics could be initiated immediately, instead of prescribing broad-spectrum antibiotics. This would provide a significant benefit to the patient in terms of saved time and avoided unnecessary pain, since they do not need to wait on culture results. Furthermore, a standardised sensor would remove human error, making diagnosis faster, easier, and objective.

\section{Volatile Organic Compounds Detection Technology and Data Analysis}

There are various competing technologies available for the analysis of VOCs in urine. The most commonly used technique is gas chromatography, coupled with mass spectrometry (GC-MS) [18]. 
Other methods include proton transfer reaction mass spectrometry (PTR-MS), ion mobility spectrometry (IMS), selected ion flow tube mass spectrometry (SIFT-MS), field asymmetric ion mobility spectrometry (FAIMS), gas chromatography flame ionisation detection (GC-FID), and electronic noses (eNoses), which are made up of arrays of sensors, e.g., metal oxide (MOS), piezoelectric, or conducting polymer (CP). A summary of the most common technologies, with a visual explanation of their working principles, is shown in Figure 1.

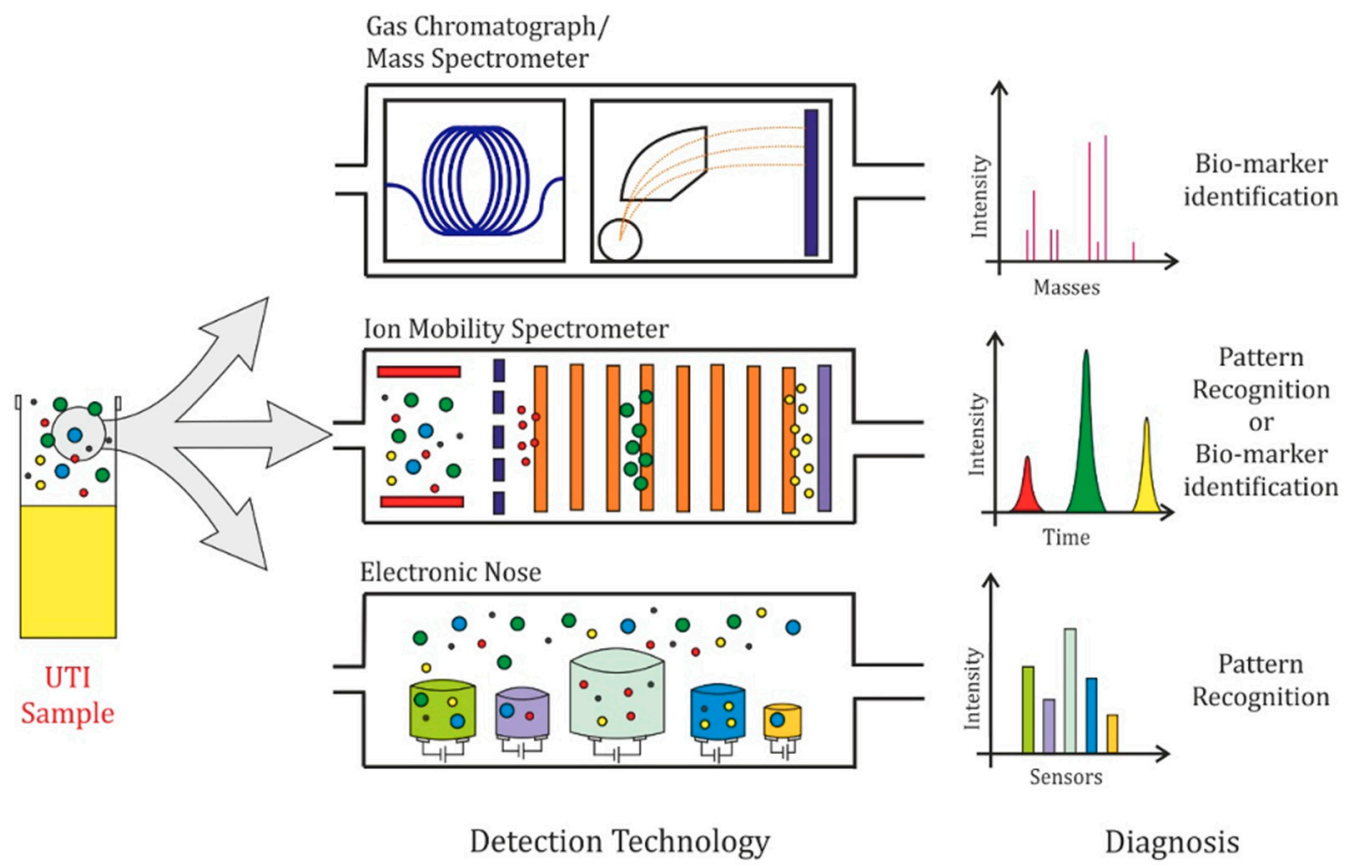

Figure 1. Volatile organic compound (VOC) detection technologies for analysis of urinary tract infection (UTI) urine samples; (Top) gas chromatography—mass spectrometry (GC-MS): the column of the GC is represented in blue, resulting in compound separation based on their physical properties and mass; (Middle) ion mobility spectrometry (IMS): the separation of compounds based on ion mobility is represented by different groups of VOCs clustering together; (Bottom) electronic nose (eNose): the eNose response is based on an array of different cross-sensitive gas sensors. A typical response is shown for each method. VOCs are illustrated as green, blue, yellow and red circles.

In GC-MS, the GC part involves injecting samples into a separation column, where they are transported by an inert carrier gas (usually helium or hydrogen). The gaseous mixture is separated into its components based on the relative interactions between the analytes and the inner coating of the column. Molecules with column interactions (e.g., lower boiling points or weight) exit the column before higher interaction compounds. The MS is then used to detect exiting compounds. An ion source is used to produce analyte ions. Electron impact ionisation is a commonly used technique, which involves bombarding the analytes with a beam of electrons. This is followed by a mass analyser, which sorts the fragment ions by their mass-to-charge ratio [39]. Lastly, the ions reach a detector (e.g., electron multiplier), which measures the ionised mass fragments as an electrical signal. GC-based technologies may also include two-dimensional GC-MS (GCxGC-MS) or combining GC with a time-of-flight mass spectrometer (GC-TOF-MS). In a GC-TOF-MS system, once the sample has passed through the GC column, the separated molecules are ionised and enter the TOF 'flight box'. TOF-MS works on the principle that when molecules are exposed to a pre-determined amount of energy, larger, heavier ions will take longer than smaller, lighter ions to travel a set distance [40].

An emerging alternative to GC-MS is IMS. This technique uses a high electric field at ambient pressure to separate different ions formed from the target analyte, based on differences in their mobility. Drift-tube IMS uses the time taken for ionized molecules to traverse the tube. These ions are 
driven along the tube by a constant high-voltage electric field. Against the flow of ions, a buffer gas (i.e., nitrogen) is used slow down the ions through collisions. This produces a time-dependent signal that corresponds with ion mobility, with its drift time being a function of the number of collisions and the ion interaction with the electric field. The drift-tube IMS method can be used in combination with GC as a pre-separator. FAIMS is a different form of IMS, which reduces the drift tube length by applying an alternating electric field across the ion path, changing the differential mobility of each ion. FAIMS has been used to diagnose various diseases including colorectal cancer [41,42]. IMS systems were originally used to detect chemical warfare agents, explosives, and illegal drugs, but have found increasing applications in the medical domain. [43].

An eNose is an instrument that attempts to replicate the function of the biological olfactory system by measuring VOCs as a whole, rather than identifying specific chemicals. It uses an array of broadly tuned (cross-sensitive) gas sensors, which are used to measure a wide range of VOCs. As each sensor in the array is different, the response between the odour and the sensor will be unique within the array. This creates an odour "fingerprint" that can be learnt by some form of pattern recognition technique. The eNose instrument types most frequently used for diagnostic applications in detecting human disease include sensor arrays made up of metal oxide sensors (MOS), electrochemical sensors (EC), conducting polymers (CP), carbon black polymer composite (CBPC), gold nanoparticles (GNP), quartz crystal microbalance (QMB) sensors, and optical sensors [44].

MOS sensors are based on a reduction-oxidation reaction. In 'clean' air, oxygen is absorbed onto the gas-sensitive layer of the sensor (e.g., tin oxide, $\mathrm{SnO}_{2}$ ). When exposed to a reducing or oxidising gas, the oxygen reacts to the target gas that changes the conductivity of the sensitive layer [45]. EC sensors are based on an electrochemical oxidation or reduction reaction, which occurs at the working electrode (WE). In the presence of VOCs, the catalytic material reacts, and produces a current at WE. A counter electrode (CE) keeps the sensor electrically neutral [46]. The operation of conducting polymer (CP) gas sensors is based on a change in conductivity of the polymer film, when exposed to analyte vapours [47]. CBPC sensors operate based on swelling of the polymer upon exposure to target gases, which in turn changes the resistance of the conducting film [48]. GNP sensors comprise of monolayer-capped gold nanoparticle chemiresistive films [49]. When exposed to VOCs, they diffuse into the sensing film and react with the capped ligands/functional groups, causing a volume shrinkage/expansion in the nanomaterial film, resulting in a change in resistance [49,50]. QMB sensors use highly sensitive quartz crystals for the measurement of the mass and viscosity of VOCs [51]. Changes in gravitational load on the sensor and viscoelastic properties of the VOCs cause a frequency shift of the quartz crystal resonator [52]. The optical sensor principle is based on absorption spectroscopy, using infrared (IR). The amount of absorption depends on the gas concentration, at a wavelength related to a target gas-selected using optical filters [53].

Each of these sensor technologies are associated with advantages and disadvantages. MOS sensors are low cost and highly sensitive but have a limited sensing range and typically operate at higher temperatures (between 300-500 ${ }^{\circ} \mathrm{C}$ ) [54]. This high temperature requirement can result in increased power consumption, while EC, CP, CBPC, GNP, and QMB sensors operate at ambient temperature and therefore require lower power. $\mathrm{CP}$ and $\mathrm{CBPC}$ sensors are inexpensive and are highly sensitive to many VOCs, but have a shorter operational life, compared to MOS sensors. They also demonstrate poor repeatability and reproducibility due to the random nature of the polymer [55]. EC sensors have fast response times, but are bulky in size and have limited sensitivity to simple or low molecular weight gases [56]. GNP sensors are newer and combine gold nanoparticles with polymers or metal-oxides. The polymer variants operate at room temperature but suffer from similar issues to CBPC sensors. The metal-oxide composite variants operate at elevated temperature and have better selectivity than normal MOS sensors, but are more challenging to fabricate [57,58]. QMB sensors have good precision for a diverse range of VOCs, but require complex circuitry, have a poor signal-to-noise ratio, and are sensitive to humidity and temperature [56]. Optical sensors have very fast response times, high sensitivity and selectivity (especially to gases such as $\mathrm{CO}_{2}$ and $\mathrm{CH}_{4}$ ), but are more expensive, 
difficult to miniaturise and may require complex electrical circuits [56]. In order to take full advantage of these characteristics, a combination of multiple sensor technologies can be deployed in a single device.

Recently, at the University of Warwick, the WOLF (Warwick olfaction) eNose was developed, which contains 13 multi-technology sensors [59]. It was successfully used to distinguish between colorectal cancer (CRC) and irritable bowel syndrome (IBS) patients [59]. While eNoses have been emerging over the past decades as a new way to diagnose a variety of complex illnesses [60], they also have downsides. Due to the nature of the sensors, they often drift over time and the response is dependent on humidity and temperature [61]. As the sensors age, chemical deterioration can damage the detecting surface of the sensor, which can cause issues with reproducibility. Without proper maintenance, even if an identical sample is tested twice, the readings could be different. Approaches to mitigate against these problems usually involve repeated sensor calibration [62].

In SIFT-MS, analytes are introduced into a flow tube and ionised with chosen precursor ions (usually $\mathrm{H}_{3} \mathrm{O}^{+}, \mathrm{NO}^{+}$or $\mathrm{O}_{2}{ }^{+}$). The resulting ions are quantified by mass filtering, using a quadrupole MS to separate the ions based on their mass-to-charge ratio. SIFT-MS has the benefit of detecting compounds and calculating the concentration from the ratio of product to precursor ions present in the headspace of the sample in real-time, as well as not requiring calibration.

Other methods, such as nuclear magnetic resonance (NMR) spectroscopy and proton transfer reaction-mass spectrometry (PTR-MS) have been used as chemical-detection technologies for VOC identification in research, but also for diagnosis [60,63-66]. In NMR spectroscopy, the atomic nuclei are excited by radio waves, resulting in nuclei orientation changes along the magnetic field. When excitation is stopped, the return to the initial lower energy orientation causes energy emissions that can be detected. This provides insight into the chemical composition of the sample [67]. In PTR-MS, VOCs undergo proton-transfer reactions (with $\mathrm{H}_{3} \mathrm{O}^{+}$ions) in a drift tube reactor and are measured by a quadrupole MS (similar to SIFT-MS) [64]. PTR-MS offers real-time analysis and has been used to test breath and urine samples for diagnosing diseases such as lung cancer and H. pylori infection [63,64,68].

Overall, eNoses and IMS have a lower purchase price, running and maintenance cost compared to GC-MS, SIFT-MS and PTR-MS. In addition, eNoses and IMS systems can be made portable and used in point-of-care applications, unlike other methods, which require laboratory settings. The disadvantages of eNoses and, in most cases, IMS are that they cannot provide an insight into the chemistry of the studied sample (e.g. chemical identification). Using GC-MS, more information about the organism growth phase and metabolic pathway can be ascertained. However, for the diagnosis of UTI, eNoses and IMS systems are still the most suitable candidates, since they are easy to use, portable, relatively low-cost, and have methods which can be automated. Table 1 provides an overview and comparison of the characteristics associated with commonly used VOC detection technologies.

Table 1. Characteristics of Volatile Organic Compound Detection Technologies.

\begin{tabular}{ccccc}
\hline Technology & \multicolumn{2}{c}{ eNoses } & IMS & GC-MS \\
\hline & CP & MOS & & \\
\hline Portability & Good & Good & Good & Poor \\
Cost & Low & Low & Low & High \\
Trained personnel & No & No & No & Yes \\
Sample throughput & High & High & Medium & Low \\
Speed & Real-time & Real-time & Real-time & Off-line \\
Metabolite detection & No & No & No & Yes \\
Pattern recognition & Yes & Yes & Yes & Yes \\
Chemical insight & No & No & Yes & Yes \\
Sensor drift & Yes & Yes & Minor & Minor
\end{tabular}

\footnotetext{
${ }^{1}$ Some IMS constructs allow for metabolite detection. Abbreviations: Electronic noses-eNoses; Ion mobility spectrometry-IMS; Gas chromatography—ion mobility spectrometry-GC-IMS; Conducting polymer-CP; Metal oxide sensors-MOS.
} 
Most applications of VOC analysis aim to discriminate between disease states. This may include a simple case-control design (e.g., disease vs. controls) or a variety of investigated states and groups. These applications predominantly rely on classification analysis to distinguish between groups and to build and train models which can be used as a diagnostic tool. The classification methods most commonly used in VOC analysis include principal component analysis (PCA), linear discriminant analysis (LDA), partial least-square discriminant analysis (PLS-DA), and machine learning (ML) algorithms. PCA is an unsupervised linear method, which reduces the dimensionality (number of features, e.g., eNose sensor responses or GC-MS peaks) of the data by selecting a small number of linearly uncorrelated principal components that explain the majority of the variation in the data [69]. LDA is a supervised linear method that tries to find a linear discriminant function to separate between study groups [70]. PLS-DA is similar to LDA but attempts to maximise the co-variance between a dummy class vector and the data matrix. PCA, LDA, and PLS-DA have been applied frequently for VOC analysis studies, for both eNose and GC-MS data [71]. The disadvantage of these methods is that they are most effective for investigating linear relationships between samples and classes (e.g., disease status). However, they not well-equipped for representing non-linear relations that are likely to be present in biological samples [72]. Non-linear statistical learning approaches, based on ML, are therefore being increasingly used for the analysis of urine VOC datasets [24,73-76]. These methods can be broadly categorised into three groups: tree-based methods (e.g., random forest-RF), neural networks, and kernel-based methods (support vector machines-SVMs). The advantage of linear techniques is that they are simple to interpret, require few parameters to be optimised, and are not computationally demanding. The converse is true of ML techniques [70].

\section{Detection of Urinary Tract Infection Using Volatile Organic Compounds}

For urine analysis, the urine sample is usually transferred to a vial/container and then sealed. The unoccupied area/air above the urine sample is known as the headspace and VOCs from the urine desorb out of the liquid phase, into this air space and can be collected for analysis. In 1976, the prospect of using headspace analysis for identifying bacteria became apparent when Hayward et al. determined that Proteus species produce methyl mercaptan and dimethyl disulfide from methionine [77]. Furthermore, P. vulgaris, P. mirabilis, P. moraganii, and P. rettgeri were shown to produce benzaldehyde. In the culture filtrate, phenylacetaldehyde and 2-phenylethanol are produced from phenylalanine. Isobutyraldehyde and isobutanol are produced from valine and isovaleraldehyde, together with isoamyl alcohol, from leucine. In uncomplemented media, isobutyraldehyde, isovaleraldehyde, and isoamyl alcohol were detected. Moreover, it was shown that $E$. coli ferments lactose or arabinose for energy and produces ethanol as a by-product.

In a paper from 1977, Hayward et al. tried to identify E. coli and Proteus species from cultures and simulated urine infections with isolated bacteria, using gas-liquid chromatography. Ethanol was suggested as an indicator for E. coli and dimethyl disulfide, together with methyl mercaptan, for Proteus species [78]. Further work by Hayward and Jeavons involved testing 75 clinical urine samples. It was found that ethanol is a biomarker for E. coli when grown in the presence of lactose and dimethyl disulfide (as well as methyl mercaptan) for Proteus mirabilis and Proteus inconstans A [79]. The analysis can be done in $3-5 \mathrm{~h}$, after urine incubation. One drawback is the inability to tell apart Klebsiella aerogenes from E. coli, since both species ferment lactose to ethanol. In a similar study, 49 strains of $E$. coli were grown in media supplemented with arabinose [80]. It was confirmed that the bacteria produce ethanol with a maximum concentration achieved after eight hours. As expected, the quantity of ethanol production is directly proportional to the total number of bacteria present in the culture, thereby providing a way to estimate the bacterial load in clinical samples. Following this, the possibility of diagnosing UTIs instigated by another organism was investigated using a similar method. P. mirabilis was found to produce dimethyl disulfide from methionine and it was once again confirmed that $E$. coli produces ethanol from arabinose in culture [81]. The advantage of growing these bacteria in enriched media, with arabinose and methionine, is that diagnosis is possible in just four hours. However, in the 
urine cultures containing K. aerogenes or K. ozaenae, ethanol was found in similar quantities as those produced by E. coli showing the decreased discriminatory power of this method [79,81].

Discrimination between E. coli and Klebsiella species using the production of ethanol from lactose (E. coli) or adonitol (Klebsiella) is also possible in less than six hours [82]. In addition, the following VOCs: trimethylamine, ethanol and ethyl acetate, were associated with P. mirabilis, P. vulgaris, P. rettgeri, and P. inconstans found via GC-MS [83]. During these experiments, it was confirmed that K. aerogenes and E. coli produces ethanol as well as ethyl acetate. It was also shown that ethyl acetate was produced by $S$. faecalis, N-propanol in E. coli's headspace, and that ethyl acetate was found in P. inconstans B [83].

These developments have paved the way to show that VOC analysis of headspace can be used to detect UTIs. This technique has three benefits: (1) it can provide chemical insight of the organism tested, (2) it can indicate the metabolic pathway used by the bacteria, and (3) indicate its growth phase. Unfortunately, this method has not gained wide-spread use in clinical settings. One reason for this could be the complexity of analysing VOCs found in the headspace of bacterial cultures. These VOCs often overlap between species, which makes discrimination very challenging.

Storer et al. used SIFT-MS to monitor 21 compounds, of eight different organisms: E. coli, P. aeruginosa, S. aureus, P. vugaris, K. pneumoniae, E. faecalis, S. epidermidis, and C. albicans. It was shown that this technology could identify a UTI in urine samples [84]. However, the urine was incubated with the bacteria for six hours, allowing for compounds to build-up in the headspace. Furthermore, the number of compounds measured did not facilitate discrimination between the different species. In contrast, a paper by Thorn et al. showed that E. coli, S. aureus, P. mirabilis, Burkholderia cepacian, and Streptococcus pyogenes could be distinguished by SIFT-MS. They monitored a set of 25 VOCs, out of which 15 were the same as the aforementioned paper [85]. This highlights both the advantage and disadvantage of this technology, i.e., the bacteria can indeed be identified, if sufficient data are available. At the same time, prior knowledge of the combination of VOCs is required to discriminate between the species. Furthermore, SIFT-MS has a high entry price point, costing even more than GC-MS.

Recently, GCxGC-TOF-MS methods were used to discover 28 new P. aeruginosa VOCs as well as confirming 28 former VOCs [86]. This area of research seemed to gain further interest between 2017-2019, since a number of works relating to this topic were published [87-93]. Most research groups used a metabolite detection approach: GC-MS [87,88], GCxGC-TOF-MS [93], and TD-GC-MS (GC-MS coupled with a thermal desorption, TD, system) [91]. DeJong et al. identified E. coli in human urine (simulated infection samples) using surface enhanced Raman spectroscopy [92].

As demonstrated, metabolite detection can be used to determine the pathogen present in urine samples. Another application is determining its antibiotic resistance. Ion-molecule reaction-mass spectrometry (IMR-MS) has been utilised to investigate whether E. coli was ampicillin resistant and $S$. aureus oxacillin resistant [94]. This was achieved by using the concentration of methanethiol as a proxy of growth in culture, in the presence or absence of antibiotics.

The various VOCs discovered to be produced by the most common UTI pathogens (in either cultures or urine samples) are shown in Table 2. There are overlaps between the species, such as ethanol, ethyl acetate, and methyl mercaptan, which are by-products of the bacterium metabolism. 
Table 2. Volatile Compounds of Different Urinary Tract Infection Pathogens.

\begin{tabular}{|c|c|c|c|c|c|c|c|c|c|c|c|c|c|}
\hline Compound & EC & PM & EF & PA & SA & KP & Compound & EC & PM & EF & PA & SA & KP \\
\hline Alcohol & & & & & & & Ester & & & & & & \\
\hline Ethanol & $\sqrt{ }$ & $\sqrt{ }$ & & $\sqrt{ }$ & $\sqrt{ }$ & $\sqrt{ }$ & ethyl acetate & $\sqrt{ }$ & $\sqrt{ }$ & & $\sqrt{ }$ & $\sqrt{ }$ & $\sqrt{ }$ \\
\hline Methanol & $\sqrt{ }$ & & & & & & $\mathrm{N}$-propylacetate & $\sqrt{ }$ & & $\sqrt{ }$ & & & \\
\hline Propanol & $\sqrt{ }$ & & & & & & n-butyl acetate & & & & & $\sqrt{ }$ & \\
\hline 1-propanol & $\sqrt{ }$ & & & & & & Ethyl phenylacetate & $\sqrt{ }$ & & & & & \\
\hline $\mathrm{N}$-propanol & $\sqrt{ }$ & & & & & & isopentyl acetate & & $\sqrt{ }$ & & $\sqrt{ }$ & $\sqrt{ }$ & $\sqrt{ }$ \\
\hline 2-(Methylthio)-ethanol & $\sqrt{ }$ & $\sqrt{ }$ & & & $\sqrt{ }$ & $\sqrt{ }$ & 3-Methylbutyl 2-methylpropanoate & & $\sqrt{ }$ & & & & \\
\hline phenol & $\sqrt{ }$ & & & & $\sqrt{ }$ & & 2-methylbutyl isobutyrate & & & & $\sqrt{ }$ & & \\
\hline Butanol & & & & $\sqrt{ }$ & $\sqrt{ }$ & & 2-Phenyl ethyl acetate & & $\sqrt{ }$ & & & & \\
\hline 1-butanol & $\sqrt{ }$ & & & & $\sqrt{ }$ & & Phenylethyl butyrate & & $\sqrt{ }$ & & & & \\
\hline 2-butanol & & $\sqrt{ }$ & & $\sqrt{ }$ & $\sqrt{ }$ & $\sqrt{ }$ & methyl 2-methylbutyrate & & & & $\sqrt{ }$ & & \\
\hline Isobutanol & & $\sqrt{ }$ & & $\sqrt{ }$ & $\sqrt{ }$ & $\sqrt{ }$ & 2-methylbutyl 2-methylbutyrate & & & & $\sqrt{ }$ & & \\
\hline 2-methyl-1-butanol & $\sqrt{ }$ & & & & & & methyl methacrylate & & & & $\sqrt{ }$ & $\sqrt{ }$ & \\
\hline 3-Methyl-1-butanol & $\sqrt{ }$ & & & $\sqrt{ }$ & $\sqrt{ }$ & $\sqrt{ }$ & ethyl 2-methylbutyrate & & & & $\sqrt{ }$ & & \\
\hline octanol & $\sqrt{ }$ & & & & & & isoamyl butyrate & & $\sqrt{ }$ & & $\sqrt{ }$ & & \\
\hline Decanol & $\sqrt{ }$ & & & & & & amyl isovalerate & & & & $\sqrt{ }$ & & \\
\hline 1-Decanol & $\sqrt{ }$ & & & & & & ethyl isovalerate & & & & & $\sqrt{ }$ & \\
\hline dodecanol & $\sqrt{ }$ & & & & & & ethyl formate & & & & & $\sqrt{ }$ & \\
\hline Benzyl Alcohol & $\sqrt{ }$ & & & & & & ethyl butanoate & $\sqrt{ }$ & & $\sqrt{ }$ & & & \\
\hline Isopentanol (isoamyl alcohol) & & $\sqrt{ }$ & & $\sqrt{ }$ & $\sqrt{ }$ & $\sqrt{ }$ & Propanoic acid 2-hydroxy-2-methyl-methyl ester & & & & & $\sqrt{ }$ & \\
\hline phenethyl alcohol & & $\sqrt{ }$ & & & & $\sqrt{ }$ & ethyl formate & & & & & $\sqrt{ }$ & \\
\hline ethylene glycol & & & & $\sqrt{ }$ & $\sqrt{ }$ & & Phenylacetic acid propylester & $\sqrt{ }$ & & & & & \\
\hline 4-methylphenol & & & & $\sqrt{ }$ & $\sqrt{ }$ & & Ketone & & & & & & \\
\hline 2-methyl-1-propanol & & & & & $\sqrt{ }$ & & acetone & $\sqrt{ }$ & & $\sqrt{ }$ & $\sqrt{ }$ & $\sqrt{ }$ & \\
\hline acetol (hydroxyacetone) & & & & & $\sqrt{ }$ & & Acetoin (3-hydroxybutanone) & $\sqrt{ }$ & & & & $\sqrt{ }$ & \\
\hline 2-phenylethyl alcohol & & & & & $\sqrt{ }$ & & butanedione (diacetyl) & $\sqrt{ }$ & & & & & \\
\hline methylbutenol & & & & $\sqrt{ }$ & $\sqrt{ }$ & $\sqrt{ }$ & Butanone & & & & $\sqrt{ }$ & $\sqrt{ }$ & $\sqrt{ }$ \\
\hline & & & & & & & 2-butanone & $\sqrt{ }$ & & $\sqrt{ }$ & $\sqrt{ }$ & & \\
\hline Aldehyde & & & & & & & 2,3-butanedione & $\sqrt{ }$ & & $\sqrt{ }$ & $\sqrt{ }$ & $\sqrt{ }$ & $\sqrt{ }$ \\
\hline Acetaldehyde & $\sqrt{ }$ & & & & $\sqrt{ }$ & & 2-heptanone & $\sqrt{ }$ & $\sqrt{ }$ & & $\sqrt{ }$ & $\sqrt{ }$ & $\sqrt{ }$ \\
\hline Benzaldehyde & $\sqrt{ }$ & & & & $\sqrt{ }$ & & 4-heptanone & & & & $\sqrt{ }$ & & \\
\hline 2-Heptenal & $\sqrt{ }$ & & & & $\sqrt{ }$ & & 2-nonanone & $\sqrt{ }$ & $\sqrt{ }$ & & $\sqrt{ }$ & $\sqrt{ }$ & $\sqrt{ }$ \\
\hline (3-methylbutanal) Isovaleraldehyde & $\sqrt{ }$ & $\sqrt{ }$ & & $\sqrt{ }$ & $\sqrt{ }$ & $\sqrt{ }$ & 2-decanone & $\sqrt{ }$ & & & & & \\
\hline 2-methylbutanal & $\sqrt{ }$ & & $\sqrt{ }$ & & $\sqrt{ }$ & & 2-hexanone & $\sqrt{ }$ & & & & & \\
\hline methylbutanal & & & & $\sqrt{ }$ & $\sqrt{ }$ & $\sqrt{ }$ & 2-Tridecanone & $\sqrt{ }$ & & & & & \\
\hline isobutyraldehyde & & $\sqrt{ }$ & & & & & 2-undecanone & $\sqrt{ }$ & $\sqrt{ }$ & & $\sqrt{ }$ & $\sqrt{ }$ & $\sqrt{ }$ \\
\hline 3-(ethylthio)-propanal & & & & $\sqrt{ }$ & & & 2,3-Heptanedione & & $\sqrt{ }$ & & & & \\
\hline Propanal & & & & & $\sqrt{ }$ & & 2-pentanone & & & $\sqrt{ }$ & $\sqrt{ }$ & $\sqrt{ }$ & \\
\hline 3-methyl-2-butenal & & & & & $\sqrt{ }$ & & 2-aminoacetophenone & $\sqrt{ }$ & & & $\sqrt{ }$ & & \\
\hline 2-ethylacrolein & & & & & $\sqrt{ }$ & & 3-octanone & & & & $\sqrt{ }$ & & \\
\hline (Z)-2-methyl-2-butenal & & & & & $\sqrt{ }$ & & methyl isobutylketone & & & & $\sqrt{ }$ & & \\
\hline (E)-2-methyl-2-butenal & & & & & $\sqrt{ }$ & & mercaptoacetone & & & & $\sqrt{ }$ & & \\
\hline
\end{tabular}


Table 2. Cont.

\begin{tabular}{|c|c|c|c|c|c|c|c|c|c|c|c|c|c|}
\hline Compound & EC & PM & EF & PA & SA & KP & Compound & EC & PM & EF & PA & SA & KP \\
\hline Methacrolein & & & & & $\sqrt{ }$ & & 1-hydroxy-2-propanone & & & & & $\sqrt{ }$ & \\
\hline 2-methylpropanal & & & & & $\sqrt{ }$ & & & & & & & & \\
\hline Nonanal & & & & & $\sqrt{ }$ & & 1-methyl-4-(1-methylethenyl)cyclohexane & $\sqrt{ }$ & & & $\sqrt{ }$ & $\sqrt{ }$ & $\sqrt{ }$ \\
\hline formaldehyde & $\sqrt{ }$ & & $\sqrt{ }$ & $\sqrt{ }$ & $\sqrt{ }$ & $\sqrt{ }$ & Acids & & & & & & \\
\hline Hydrocarbons & & & & & & & isobutyric acid & & & & & $\sqrt{ }$ & \\
\hline Toluene & $\sqrt{ }$ & $\sqrt{ }$ & $\sqrt{ }$ & & $\sqrt{ }$ & $\sqrt{ }$ & Butyric acid & & & & & $\sqrt{ }$ & \\
\hline 1-Methyl-naphthalene & $\sqrt{ }$ & & & & & & 4-methylhexanoic acid & & & & & $\sqrt{ }$ & \\
\hline 2-Methyl-naphthalene & $\sqrt{ }$ & & & & & & Picolinic acid N-oxide & $\sqrt{ }$ & & & & & \\
\hline Isoprene & $\sqrt{ }$ & & & $\sqrt{ }$ & & & Isoamyl benzoate & & $\sqrt{ }$ & & & & \\
\hline 2-Butene & $\sqrt{ }$ & & & & & & Sulphur & & & & & & \\
\hline (Z)-2-butene & & & & & $\sqrt{ }$ & & methyl mercaptan (Methanethiol) & $\sqrt{ }$ & $\sqrt{ }$ & $\sqrt{ }$ & $\sqrt{ }$ & $\sqrt{ }$ & $\sqrt{ }$ \\
\hline (E)-2-butene & & & & & $\sqrt{ }$ & & dimethyl disulfide & $\sqrt{ }$ & $\sqrt{ }$ & $\sqrt{ }$ & $\sqrt{ }$ & $\sqrt{ }$ & $\sqrt{ }$ \\
\hline Undecane & & & & $\sqrt{ }$ & & $\sqrt{ }$ & dimethyl sulfide & $\sqrt{ }$ & & $\sqrt{ }$ & $\sqrt{ }$ & & $\sqrt{ }$ \\
\hline 2,4-dimethylheptane & & $\sqrt{ }$ & $\sqrt{ }$ & & $\sqrt{ }$ & $\sqrt{ }$ & dimethyl trisulfide & $\sqrt{ }$ & $\sqrt{ }$ & & $\sqrt{ }$ & $\sqrt{ }$ & \\
\hline 3-methylheptane & $\sqrt{ }$ & & & & & & Benzyl methyl sulfide & & $\sqrt{ }$ & & & & \\
\hline undecene & & & & $\sqrt{ }$ & & & 2-methoxy-5-methylthiophene & & & & $\sqrt{ }$ & & \\
\hline 1-undecene & & & & $\sqrt{ }$ & & & S-Methyl thiobenzoate & & $\sqrt{ }$ & & & & \\
\hline 2-methyl-2-butene & & & & $\sqrt{ }$ & & & 2,4-dithiapentane & & $\sqrt{ }$ & & & & \\
\hline 1,10-undecadiene & & & & $\sqrt{ }$ & & & & & & & & & \\
\hline 1-nonene & & & & $\sqrt{ }$ & & & Chlorine & & & & & & \\
\hline 2-Nonene & & & & & $\sqrt{ }$ & & Trichloromethane & $\sqrt{ }$ & & & & $\sqrt{ }$ & \\
\hline 1-decene & & & & $\sqrt{ }$ & & & 4-Chloro-1H-indole & $\sqrt{ }$ & & & & & \\
\hline 1-dodecene & & & & $\sqrt{ }$ & & & & & & & & & \\
\hline Butane & & & & $\sqrt{ }$ & & & Inorganic & & & & & & \\
\hline n-butane & & & & & $\sqrt{ }$ & & ammonia & $\sqrt{ }$ & & $\sqrt{ }$ & & $\sqrt{ }$ & $\sqrt{ }$ \\
\hline 10-methyl-1-undecene & & & & $\sqrt{ }$ & & & Hydrogen Sulfide & $\sqrt{ }$ & & $\sqrt{ }$ & & & $\sqrt{ }$ \\
\hline 1,3-butadiene & & & & & $\sqrt{ }$ & & & & & & & & \\
\hline 2-methylpropene & & & & & $\sqrt{ }$ & & Other & & & & & & \\
\hline Propane & & & & & $\sqrt{ }$ & & pyrazine derivative & $\sqrt{ }$ & & & & & $\sqrt{ }$ \\
\hline 2-Nonene, 3-methyl & & & & & $\sqrt{ }$ & & benzene derivative & $\sqrt{ }$ & $\sqrt{ }$ & & $\sqrt{ }$ & $\sqrt{ }$ & $\sqrt{ }$ \\
\hline 2,3,4-Trimethylhexane & $\sqrt{ }$ & & & & & & phenol derivative & $\sqrt{ }$ & $\sqrt{ }$ & & & & $\sqrt{ }$ \\
\hline hexane & $\sqrt{ }$ & & & & & & pentanone/toluene & & & & $\sqrt{ }$ & $\sqrt{ }$ & $\sqrt{ }$ \\
\hline 2,3,3-trimethylpentane & $\sqrt{ }$ & & & & & & & & & & & & \\
\hline Acetic acid & $\sqrt{ }$ & & & $\sqrt{ }$ & $\sqrt{ }$ & & Nitrogen & & & & & & \\
\hline Isovaleric acid & & & & & $\sqrt{ }$ & & indole dimer & $\sqrt{ }$ & & & & & \\
\hline 2-methylbutyric acid & & & & & $\sqrt{ }$ & & ethylamine & & $\sqrt{ }$ & & & & \\
\hline & & & & & & & Indole & $\sqrt{ }$ & & & $\sqrt{ }$ & & \\
\hline Nitrogen & & & & & & & 3-Methyl-1H-indole & $\sqrt{ }$ & & & & & \\
\hline methylpyrazine & $\sqrt{ }$ & & & $\sqrt{ }$ & & & Cadaverine & $\sqrt{ }$ & $\sqrt{ }$ & & & & \\
\hline benzonitrile & $\sqrt{ }$ & $\sqrt{ }$ & & $\sqrt{ }$ & $\sqrt{ }$ & & putrescine & & $\sqrt{ }$ & & & & \\
\hline 2,3,5-trimethylpyrazine & $\sqrt{ }$ & & & & & & Acetonitrile & $\sqrt{ }$ & & & $\sqrt{ }$ & $\sqrt{ }$ & \\
\hline $\mathrm{N}$-(Phenylmethylene)-methanamine & $\sqrt{ }$ & & & & & & beta-phenylethylamine & & $\sqrt{ }$ & & & & \\
\hline
\end{tabular}


Table 2. Cont

\begin{tabular}{|c|c|c|c|c|c|c|c|c|c|c|c|c|c|}
\hline Compound & EC & PM & EF & PA & SA & KP & Compound & EC & PM & EF & PA & SA & KP \\
\hline $\mathrm{N}, \mathrm{N}^{\prime}$-Dibenzylideneethylenediamine & $\sqrt{ }$ & & & & & & & & & & & & \\
\hline $\mathrm{N}$-(Phenylmethylene)-1-propanamine & $\sqrt{ }$ & & & & & & References & [95] & [96] & [84] & [95] & [96] & [83] \\
\hline N-(Phenylmethylene)-1-butanamine & $\sqrt{ }$ & $\sqrt{ }$ & & & & & & [97] & [84] & [93] & [84] & [84] & [84] \\
\hline n-nitrosodimethylamine & & $\sqrt{ }$ & & & & & & [83] & [83] & & [93] & [93] & [96] \\
\hline pyrrolidine & & $\sqrt{ }$ & & & & & & [80] & [98] & & [99] & [99] & [93] \\
\hline Isoamylamine & & $\sqrt{ }$ & & & & & & [81] & [81] & & [100] & [100] & {$[100]$} \\
\hline Isobutylamine & & $\sqrt{ }$ & & & & & & [93] & [101] & & [102] & [103] & {$[104]$} \\
\hline 3-Methyl-N-(3-methylbutylidene)-1-butanamine & & $\sqrt{ }$ & & & & & & [99] & [77] & & [105] & [106] & \\
\hline Benzyl nitrile & & $\sqrt{ }$ & & & & & & [100] & [91] & & [107] & [91] & \\
\hline N-Butyl-benzenamine & & $\sqrt{ }$ & & & & & & [108] & [100] & & [103] & [104] & \\
\hline 2-(3-Methylbutyl)-3,5-dimethylpyrazine & & $\sqrt{ }$ & & $\sqrt{ }$ & & & & [105] & & & [106] & & \\
\hline 3-Methyl-N-(2-phenylethylidene)-1-butanamine & & $\sqrt{ }$ & & & & & & [109] & & & [104] & & \\
\hline p-Pentylaniline & & $\sqrt{ }$ & & & & & & [110] & & & & & \\
\hline N-(1,1-Dimethylethyl)-benzamide & & $\sqrt{ }$ & & & & & & {$[91,104]$} & & & & & \\
\hline N-n-Butylphthalimide & & $\sqrt{ }$ & & & & & & & & & & & \\
\hline 4-methyl-quinazoline & & & & $\sqrt{ }$ & & & & & & & & & \\
\hline Dimethylpyrazine & & & & $\sqrt{ }$ & & & & & & & & & \\
\hline pyrrole & & & & $\sqrt{ }$ & & & & & & & & & \\
\hline 3-methylpyrrole & & & & $\sqrt{ }$ & & & & & & & & & \\
\hline 1-vinyl aziridine & & & & $\sqrt{ }$ & & & & & & & & & \\
\hline Pyrimidine & & & & & $\sqrt{ }$ & & & & & & & & \\
\hline 2-Acetylthiazole & & $\sqrt{ }$ & & & & & & & & & & & \\
\hline Trimethylamine & $\sqrt{ }$ & $\sqrt{ }$ & & & & $\sqrt{ }$ & & & & & & & \\
\hline
\end{tabular}

Abbreviations: EC—Escherichia coli, PM—Proteus mirabilis, EF—Enterococcus faecalis, PA—Pseudomonas aeruginosa, SA—Staphylococcus aureus, KP—Klebsiella pneumoniae. 
The same pathogens responsible for UTI can also cause infections in other parts of the body, such as the lungs, blood, or burn wounds. The fact that VOCs identified in urine specimen culture, or pure culture, overlap with VOCs found in the headspace of the same bacteria from different clinical specimens confirms that the bacteria is being detected. For example, 2-aminoacetophenone is the compound responsible for the grape-like odour of P. aeruginosa and was found from clinical isolates from the Burn Unit of the University of Iowa Hospitals. Furthermore, 2,4-Dimethylquinazoline and 4-Mehtylquinazoline were also found [111]. In addition, SIFT-MS was used on cultures of P. aeruginosa from cystic fibrosis patients [112]. Simulated blood infections and blood culture bottles with E. coli, P. aeruginosa and S. aureus were analysed by SIFT-MS, confirming previously found products [113-115], with antibiotic resistance of $E$. coli to gentamicin and S. aureus to flucloxacillin, determined by VOC suppression in culture [113]. E. coli resistance to gentamicin was determined using SIFT-MS-after $22 \mathrm{~h}$ of incubation, the production of hydrogen sulfide from the bacteria was eliminated (acetic acid, 2-aminoacetophenone, ethanol, methanethiol, pentanols, propanol, and dimethyl disulfide were also inhibited). When S. aureus's headspace was analysed, 2-aminoacetophenone, ethanol and formaldehyde production were found to be inhibited by flucloxacillin [113]. GC-MS has been used on infected sinus mucus with bacterial species including S. aureus and P. aeruginosa [103]. In the lung of cystic fibrosis patients, colonized with P. aeruginosa, 2-aminoacetophenone was found by GC-MS breath analysis, but also in the headspace of the cultured organisms [116]. The headspace of E. coli, P. aeruginosa, K. pneumoniae, and S. aureus from inoculated artificial sputum medium or nutrient broth was tested with GC-TOF-MS [117]. Similarly, GC-IMS has been deployed to analyse the headspace of blood cultures containing E. coli, S. aureus and P. aeruginosa [118]. A study involving 210 samples of bronchoalveolar lavages found volatile fatty acids in the headspace of Candida alibicans, Enterococcus faecalis, Pseudomonas aeruginosa, K. pneumoniae, Proteus species, S. aureus, and other bacteria [119]. Using clinical blood cultures and reference strain bacterial blood cultures, volatile fatty acids were detected in a number of UTI relevant pathogens [120]. IMR-MS was also used to distinguish between Gram-negative and Gram-positive bacteria from positive blood culture samples, with some of the bacteria also being responsible for UTI: S epidermidis $(n=87)$, S. aureus $(n=17)$, E. coli $(n=30)$, and K. pneumoniae $(n=8)$ [121].

\section{Electronic Nose and Ion Mobility Spectrometry Use}

There have been a number of studies that utilised eNoses to detect UTI. In 2001, the Osmetech Microbial Analyzer (OMA) polymer sensor array was used directly on 534 urine samples and discriminated between infected from non-infected samples, at a cut-off of $10^{5} \mathrm{CFU} / \mathrm{mL}$, with a sensitivity of $83.48 \%$ and specificity of $87.59 \%$ using principal component analysis (PCA) [122].

Despite these promising results, the drawback of this study is that it only provides information about the infection status of the patient, without identifying the causative agent. The following year (2002), a different eNose system (the Bloodhound BH114) was used to not only identify UTIs but also the bacterial agent [123]. A limitation of this study was that samples were cultured for 4.5 or five hours, making the sample processing time similar to the previously discussed GC-based work, without providing chemical identification. A total of 45 samples were analysed, including 30 UTI cases. Using genetic algorithms and back-propagation neural networks, discrimination between E. coli, Proteus spp., and coagulase negative Staphylococcus spp. was possible with $98 \%$ prediction rate (31 training samples and 14 tests with 13 out of 14 correctly identified) or $95 \%$ prediction rate (26 training samples and 19 tests with 18 out of 19 recognised) depending on which neural network was applied. Another study in 2008 by Kodogiannis et al. demonstrated that the Bloodhound BH114 can be used to discriminate the same species, this time, achieving $100 \%$ accuracy with four feature extraction approaches (divergence, absorption, desorption, and area) [124].

Similarly, the Cyranose Sciences' Cyranose 320 eNose was used in parallel with an Agilent 4440 Chemosensor mass spectrometer to discriminate between infected and healthy urine samples, without any prior culturing [125]. One of the problems faced when using this setup is the amount of data 
generated in a single experiment. As such, the paper investigated different data reduction approaches including multilayer perceptron, radial basis function (RBF) neural networks and autoregressive exogeneous models. In the urine screening experiments, 189 sensor responses from the Cyranose 320 eNose were used, with an ARX (autoregressive exogenous type) model, to achieve an accuracy of $65 \%$ with data from all 32 sensors and $67 \%$ using 19 sensors (most negatively correlating). Furthermore, $71 \%$ accuracy was achieved when that was coupled with normalising. The accuracy obtained using another approach (RBF) was 50\%, with correlation results of $65 \%$ and $80 \%$ with the Hybrid NARX model (73\% was achieved when sensor numbers were reduced) [125].

Further studies have been conducted since 2011 [84,85]. Sabeel et al. used the Cyranose 320 eNose to analyse urine containing either bacteria (one sample) or mucus (six samples), compared to healthy urine (two samples). The drawback of this study is the small sample size and that no data accuracy was provided [126]. In a later study, the ChemPro 100i (a device combining a type of IMS with MOS gas sensors) was used in a proof-of-principle study with 101 bacterial cultures from urine containing: E. coli, S. saprophyticus, Klebsiella species as well as E. faecalis [127]. The ChemPro100i achieved a sensitivity and specificity of $90 \%$ and $96 \%$, respectively, (using linear discriminant analysis-LDA) to identify the bacteria and $95 \%$ and $97 \%$, respectively, to distinguish between healthy and infected samples (using logistic regression) [127]. This study demonstrated that accurate discrimination between healthy and infected urine is possible, when different bacteria is present, using pattern recognition techniques. The main advantage of using ChemPro 100i for UTI diagnosis is that the device is portable (handheld), thereby facilitating point-of-care use.

In a study by Ratiu et al., the ChemPro 100i was used to discriminate between three bacterial species (E. coli, Bacillus subtilis and S. aureus) [91]. In more recent work by Adebiyi et al., a new eNose, produced by IBM, called the Electronic Volatile Analyzer (EVA) was used to differentiate strains of E. coli-inoculated urine. A key feature of the new eNose is that it is intended for internet-of-things (IoT) applications. By using different statistical methods, various accuracies were achieved by the EVA eNose with, on average, over $90 \%$, and some with even $100 \%$ [90]. Overall, current developments in pattern recognition devices suggest that it is possible to detect specific bacteria in the VOC headspace of urine. Table 3 provides a summary of these developments. 
Table 3. Urinary Tract Infection and Pathogen Volatile Organic Compounds Detection.

\begin{tabular}{|c|c|c|c|c|}
\hline Reference and Year & Technology & Number & Culture for Headspace Analysis & Experiment/Findings \\
\hline Hayward et al. [77], 1977 & Gas-liquid chromatograph & 68 strains & $\begin{array}{l}\text { Basal defined media with potassium lactate, } \\
\text { amino acids and salts. Nutrient Broth (Oxoid) } \\
\text { and MacConkey agar (Oxoid). Incubation } \\
\text { still/shaken }(160 \mathrm{rpm}) \text { at } 37^{\circ} \mathrm{C}\end{array}$ & $\begin{array}{l}\text { Samples were mechanically shaken for } 5 \mathrm{~min} \text { at } 37^{\circ} \mathrm{C} \text { followed by } 3 \mathrm{~min} \\
\text { incubation at } 60^{\circ} \mathrm{C} \text { prior to analysis. It was found that Proteus species will } \\
\text { produce dimethyl disulfide and methyl mercaptan from L-methionine. }\end{array}$ \\
\hline Hayward et al. [78], 1977 & Gas-liquid chromatograph & 14 bacterial species & $\begin{array}{l}\text { Basal defined media with lactate, amino acids, } \\
\text { salts and vitamins cultured still at } 37^{\circ} \mathrm{C} \text { or } \\
\text { yeast extract broth still/shaken at } 160 \mathrm{rpm} .\end{array}$ & $\begin{array}{l}\text { Proteus mirabilis produces dimethyl disulfide and methyl mercaptan when } \\
\text { cultured with L-methionine. E. coli produces ethanol from lactose. Detection of } \\
\text { E. coli and P. mirabilis in urine based on ethanol production was achieved in } 5 \mathrm{~h} \\
\text { (ethanol for E. coli methyl mercaptan for P. mirabilis) or } 4 \mathrm{~h} \text { (dimethyl disulfide } \\
\text { for } P \text {. mirabilis). Other bacteria tested for dimethyl disulfide, methyl mercaptan } \\
\text { or ethanol production were: C. freundii, E. cloacae, S. marcescens, K. aerogenes, } \\
\text { K, oxytoca, K. ozaenae, P. aeruginosa, S. aureus, S. epidermidis, S. marcescens and } \\
\text { S. faecalis. Samples were mechanically shaken for } 5 \text { min at } 37^{\circ} \mathrm{C} \text { followed by } \\
\text { 3 min incubation at } 60^{\circ} \mathrm{C} \text { prior to analysis. }\end{array}$ \\
\hline Coloe et al. [80], 1978 & Gas-liquid chromatograph & 49 strains & $\begin{array}{l}24 \mathrm{~h} \text {, unshaken cultures. Media: arabinose, } \\
\text { amino acid mixture, salt mixture, } \mathrm{pH} 7.4, \\
\text { nicotinic acid }(0.5 \mathrm{mg}) \text { and calcium } \\
\text { pantothenate }\end{array}$ & $\begin{array}{l}\text { 39/49 clinical samples: urine-29, faeces-8, pus-1, sputum-1. E. coli } \mathrm{H} 19 \\
\text { incubation resulted in ethanol production from arabinose (maximum } \\
\text { concentration after } 8 \mathrm{~h} \text { ). For headspace analysis the mixture (culture fluid with } \\
6 \mathrm{~g} \text { of anhydrous } \mathrm{K}_{2} \mathrm{CO}_{3} \text { ) was shaken at } 160 \mathrm{rpm} \text { at } 37^{\circ} \mathrm{C} \text { for } 5 \text { min and then } \\
\text { heated at } 60^{\circ} \mathrm{C} \text { in a water bath for } 5 \mathrm{~min} \text {. }\end{array}$ \\
\hline Coloe et al. [81], 1978 & Gas-liquid chromatograph & 122 urine samples & $\begin{array}{l}37^{\circ} \mathrm{C}, 4 \mathrm{~h} \text { shaking in } 6 \mathrm{~mL} \text { yeast-extract } \\
\text { peptone water enriched with arabinose and } \\
\text { methionine }\end{array}$ & $\begin{array}{l}94 \text { samples from UTI suspected patients, } 28 \text { uninfected controls. Results } \\
\text { available in } 4 \mathrm{~h} \text {. E. coli produces ethanol from arabinose and P. mirabilis } \\
\text { dimethyl disulfide from methionine. }\end{array}$ \\
\hline Hayward et al. [128], 1983 & Gas-liquid chromatograph & 382 urine samples & $\begin{array}{l}\text { Methionine yeast-extract peptone medium } \\
\text { supplemented with arabinose incubated } \\
\text { for } 3.5 \mathrm{~h} .\end{array}$ & $\begin{array}{l}\text { E. coli, Klebsiella, Citrobacter and Proteus species. Ethanol production from } \\
\text { lactose/arabinose of E. coli and methyl mercaptan from methionine of } \\
\text { Proteus spp (methyl mercaptan oxidizes to dimethyl disulfide). No false } \\
\text { positives and false negatives. Liquid was heated to } 60^{\circ} \mathrm{C} \text { for headspace } \\
\text { sampling. }\end{array}$ \\
\hline Manja et al. [82], 1983 & Gas-chromatography & 96 urine samples & $\begin{array}{c}\text { E. coli detection M-9 salt mixture, } \\
\text { M-9L medium at } 44^{\circ} \mathrm{C}, 5 \mathrm{~h} \text {. Klebsiella detection } \\
\text { M-9A medium (M-9L with lactose replaced by } \\
\text { adonitol and carbenicillin), } 37^{\circ} \mathrm{C} \text {. }\end{array}$ & $\begin{array}{l}16 \text { cases caused by } E \text { coli, } 4 \text { by Klebsiella and } 2 \text { were missed by GC. Ethanol } \\
\text { presence indicates the bacteria present (in M-9L of } E \text {. coli and in M-9A of } \\
\text { Klebsiella). All samples cultured in both media. }\end{array}$ \\
\hline Davies et al. [83], 1984 & Gas-liquid chromatograph & 125 strains & $\begin{array}{l}\text { Urine culture, } 37^{\circ} \mathrm{C}, 3.5 \mathrm{~h} \text {, unshaken, media } \\
\text { made of yeast-extract peptone } \\
\text { medium concentrate. }\end{array}$ & $\begin{array}{l}\text { For headspace samples-liquid temperature } 60^{\circ} \mathrm{C} \text { for } 5 \text { min. Production of } \\
\text { trimethylamine from acetylcholine biomarker for } P \text {. mirabilis, P. vulgaris, } \\
\text { P. retgeri, P. inconstants A (not in P. morganii and P. inconstans B). Same species } \\
\text { also produced ethanol and ethyl acetate. Ethanol production from arabinose } \\
\text { was found in E. coli, K. aerogenes, all strains of S. faecalis. Ethyl acetate } \\
\text { produced by K. aerogenes, S. faecalis, E. coli (with n-propanol) and P. inconstans } \\
\text { B. No VOCs found P. morganii, S. epidermidis, S. aureus, P. aeruginosa. }\end{array}$ \\
\hline Aathithan et al. [122], 2001 & $\begin{array}{l}\text { Osmetech Microbial } \\
\text { Analyzer (OMA) Polymer } \\
\text { sensor array }\end{array}$ & 534 clinical samples & No & $\begin{array}{c}\text { Sensitivity of } 83.48 \% \text {, specificity of } 87.59 \% \text { (infection defined } \\
\text { as }>1 \times 10^{5} \mathrm{CFU} / \mathrm{mL} \text { ). } 72.3 \% \text { sensitivity and } 89.38 \% \text { Specificity at } 10^{4} \mathrm{CFU} / \mathrm{mL} \\
\text { cut-off. Threshold PCA values were set using control experiments with } \\
\text { reconstituted urine specimens inoculated with bacteria ( } 4 \text { cultures for each } \\
\text { organism—result average } 4 \text { replicates) } 4 \text { blanks for each organism. } \\
\text { Organisms: E. coli, E. faecalis, S. aureus, Klebsiella spp., S. saprophyticus } \\
\text { and P. mirabilis }\end{array}$ \\
\hline
\end{tabular}


Table 3. Cont

\begin{tabular}{|c|c|c|c|c|}
\hline Reference and Year & Technology & Number & Culture for Headspace Analysis & Experiment/Findings \\
\hline Pavlou et al. [123], 2002 & Bloodhound BH114 & 25 and 45 urine samples & $\begin{array}{l}4.5 \mathrm{~h} \text { incubation in enhanced media at } 37^{\circ} \mathrm{C} \text {. } \\
\text { Media included: } 60 \% \text { brain heart infusion } \\
\text { broth, } 40 \% \text { cooked meat broth. }\end{array}$ & $\begin{array}{c}37^{\circ} \mathrm{C} \text { water bath for VOC sampling. First experiment: } 20 \text { out of } 25 \text { samples } \\
\text { UTI confirmed- } 9 \text { E. coli, } 5 \text { P. mirabilis, } 6 \text { mixed infection of gram positive cocci } \\
\text { and Proteus species, } 5 \text { normal urine samples. Genetic Algorithms, } \\
\text { Back-Propagation Neural Networks (GA-NN) used-100\% prediction on the } \\
\text { training set, the } 9 \text { samples not used for training were successfully identified. } \\
\text { Second experiment: } 30 \text { out of } 45 \text { samples UTI- } 13 \text { E.coli, } 9 \text { Proteus. spp, } \\
8 \text { coagulase negative Staphylococcus species. First NN } 98 \% \text { prediction rate, } \\
\text { 13/14 unknown samples identified correctly. Second NN } 95 \% \text { prediction } \\
\text { rate- } 18 / 19 \text { unknown identified. }\end{array}$ \\
\hline Yates et al. [125], 2005 & $\begin{array}{l}\text { Cyranose } 320 \text { electronic } \\
\text { nose and Agilent } \\
4440 \text { Chemosensor }\end{array}$ & $\begin{array}{l}189 \text { Sensor Responses for } \\
\text { Urine (Cyranose 320) }\end{array}$ & No & $\begin{array}{l}\text { Data reduction and optimisation using non-linear model with a kernel width } \\
\text { parameter achieved } 80 \% \text { accuracy. Different statistical methods were used } \\
\text { accuracy attained: ARX model } 65 \% \text {, } 67 \% \text { (using data from } 19 / 32 \text { sensors), } \\
71 \% \text { using the most negatively correlated sensor; RBF- } 50 \% \text {, using correlation } \\
\text { results } 65 \% \text {, Hybrid NARX model- } 80 \% \text {. ( } 73 \% \text { when sensor number } \\
\text { was reduced). }\end{array}$ \\
\hline Yates et al. [129], 2005 & Agilent 4440 & $\begin{array}{l}28 \text { and } 40 \text { samples for } \\
\text { S. aureus. } 32 \text { data points } \\
\quad \text { for E. coli }\end{array}$ & Yes & $\begin{array}{l}\text { Agilent } 4440 \text { was used along with a pattern recognition algorithm (radial basis } \\
\text { function network) to distinguish between methicillin resistant and susceptible } \\
\text { S. aureus }(100 \% \text { accuracy obtained) and identify the growth phase of E. coli } \\
(68.75 \% \text { and } 81.25 \% \text { accuracy)-Chowever the ones missed were misclassified } \\
\text { by one growth stage. }\end{array}$ \\
\hline $\begin{array}{l}\text { Kodogiannis et al. } \\
{[124], 2008}\end{array}$ & Bloodhound BH114 & 45 urine samples & $\begin{array}{l}\text { Culture with Volatile generating kit, } \\
5 \mathrm{~h} \text { incubation at } 37^{\circ} \mathrm{C}\end{array}$ & $\begin{array}{l}\text { Headspace sample }-37^{\circ} \mathrm{C} \text { water bath. } 45 \text { samples, } 30 \text { UTI (confirmed by } \\
\text { microscopy + culture) - } 13 \text { E. coli, } 9 \text { Proteus spp, } \\
8 \text { coagulase - Staphylococcus spp. } 31 \text { samples used for training, } 14 \text { for } \\
\text { validation. Averaging the output of } 4 \text { feature-based networks (Divergence, } \\
\text { Absorption, Desorption, Area) the overall accuracy was } 100 \% \text {. }\end{array}$ \\
\hline Bruins et al. [130], 2009 & MonoNose & 52 strains & $\begin{array}{l}\text { BD-BACTECTM_Plus-Anaerobic/FMedium } \\
\text { with the addition of } 0.1 \mathrm{mM} \mathrm{FeCl}_{3} \text { for } \\
\text { measurements. Other commercially available } \\
\text { culture broths with different chemicals added } \\
\text { were also tested }\end{array}$ & $\begin{array}{l}104 \text { measurements taken. Bacterial species tested: Escherichia coli, } \\
\text { Proteus mirabilis, Enterococcus faecalis, Pseudomonas aeruginosa, } \\
\text { Klebsiella pneumoniae, Staphylococcus aureus, Klebsiella oxytoca, } \\
\text { Enterobacter cloacae, Clostridium difficile and Salmonella enteriditis, } \\
\text { Salmonella typhimurium. Specificity varied with the organism tested-between } \\
67 \% \text { and } 100 \% \text {. }\end{array}$ \\
\hline Storer et al. [84], 2011 & SIFT-MS & $\begin{array}{l}90 \text { (10 replicate samples for } \\
\text { each microbe) }\end{array}$ & Inoculation of sterile urine for $6 \mathrm{~h}$. & $\begin{array}{c}10 \text { samples of inoculated urine for each pathogen: E. coli, Proteus vulgaris, } \\
\text { P. aeruginosa, S. aureus, S. epidermidis, K. pneumoniae, E. faecalis, } \\
\text { or Candida albicans. Presents a table with mean concentration of different } \\
\text { VOCs in the urine headspace. }\end{array}$ \\
\hline Thorn et al. [85], 2011 & SIFT-MS & $\begin{array}{l}11 \text { strains ( } 66-3 \text { repeats for } \\
\text { each strain at } 5 \mathrm{~h} \text { and } 24 \mathrm{~h} \text { ) }\end{array}$ & $\begin{array}{l}\text { Bacterial plate cultures }(20-24 \mathrm{~h} \text { after } \\
\text { inoculation) were emulsified in } 5 \mathrm{~mL} \text { of } 1 \% \\
\text { tryptone- } 0.5 \% \text { yeast extract broth, incubated at } \\
37^{\circ} \mathrm{C} \text {, orbital shaking, } 200 \mathrm{rpm}, 24 \mathrm{~h} \text {. }\end{array}$ & $\begin{array}{l}\text { P. aeruginosa, S. aureus, E. coli, P. mirabilis, Burkholderia cepacian, S. pyogenes and } \\
\text { E. faecalis were studied. Control media sampling was also used }(n=36) \text {. } \\
\text { Table with the different VOCs presented and discrimination between species } \\
\text { is possible. }\end{array}$ \\
\hline Wiesner et al. [94], 2011 & IMR-MS & 4 strains & $\begin{array}{l}\text { Liquid cultures in Muller-Hinton medium } \\
\text { shaken at } 200 \mathrm{rpm} \text { and } 37^{\circ} \mathrm{C}\end{array}$ & $\begin{array}{l}\text { Antibiotic sensitive/resistant bacteria strain identification. Two strains of } \\
\text { E. Coli (one sensitive and one ampicillin resistant) and two S. aureus strains } \\
\text { (oxacillin sensitive/resistant) were used. }\end{array}$ \\
\hline Bean et al. [86], 2012 & GCxGC-TOF-MS & $\begin{array}{l}2 \text { PA14 cultures and one } \\
\text { LB-Lennox blank }\end{array}$ & $24 \mathrm{~h}$ culture at $37^{\circ} \mathrm{C}$ in lysogeny broth, Lennox & $\begin{array}{l}\text { Discovered } 28 \text { new volatiles for } P \text {. aeruginosa PA14, } 56 \text { compounds in total. } \\
\text { Samples heated and stirred for } 10 \text { min at } 50^{\circ} \mathrm{C} \text {. Solid-phase microextraction } \\
\text { SPME was used for headspace sampling PA14 strains. }\end{array}$ \\
\hline
\end{tabular}


Table 3. Cont

\begin{tabular}{|c|c|c|c|c|}
\hline Reference and Year & Technology & Number & Culture for Headspace Analysis & Experiment/Findings \\
\hline Jünger et al. [100], 2012 & MCC-IMS & 15 human pathogens & $24 \mathrm{~h}$ at $37^{\circ} \mathrm{C}$ on Columbia sheep blood agar. & $\begin{array}{l}\text { Detection of VOC for E. coli, P. aeruginosa, P. mirabilis, K. pneumoniae, S. aureus, } \\
\text { S. epidermidis and other species using MCC-IMS in negative and positive ion } \\
\text { mode as well as GC/MS for confirmation. }\end{array}$ \\
\hline Sabeel et al. [126], 2013 & Cyranose 320 & 13 urine samples, selected 9 & No & $\begin{array}{l}\text { Cyranose } 320 \text { was introduced in } 2 \mathrm{~mL} \text { of urine } 10 \text { times for each of the } \\
13 \text { samples. PCA was used for analysis (first component explained } 97.087 \% \text { of } \\
\text { the variation). } 9 \text { samples were selected and classified as healthy (2), } \\
\text { containing bacteria (1), containing mucus (9)-UTI marker. }\end{array}$ \\
\hline Roine et al. [127], 2014 & $\begin{array}{l}\text { ChemPro 100i, Environics } \\
\text { Inc., Mikkeli, Finland }\end{array}$ & $\begin{array}{l}101 \text { Cultures from } \\
\text { clinical samples }\end{array}$ & $\begin{array}{l}\text { Cysteine lactose electrolytedeficient } \\
\text { (CLED) medium }\end{array}$ & $\begin{array}{l}\text { Pathogens: E. Coli, S. saprophyticus, Klebsiella spp, E. faecalis. Samples } \\
\text { introduced in } 36^{\circ} \mathrm{C} \text { water bath for } 15 \text { min prior to headspace analysis. } \\
\text { LDA and LR were used. Infected/non-infected discrimination LR- } 95 \% \\
\text { sensitivity, } 97 \% \text { specificity; LDA- } 20 \% \text { sensitivity, } 96 \% \text { specificity. } \\
\text { Bacterial discrimination } 95 \% \text { sensitivity } 96 \% \text { specificity LDA. } \\
\text { Validation method leave one out (LOOCV). }\end{array}$ \\
\hline Boots et al. [104], 2014 & GC-MS & $\begin{array}{l}200 \text { ( } 40 \text { cultures for } \\
\text { each bacteria) }\end{array}$ & $\begin{array}{l}\text { Overnight culture, } 37^{\circ} \mathrm{C} \text {, blood agar plates. } \\
\text { Bacteria transferred to sterile brain heart } \\
\text { infusion broth for } 4 \mathrm{~h} \text {, agitated at } 37^{\circ} \mathrm{C} \text {. }\end{array}$ & $\begin{array}{l}4 \text { bacteria studied: P. aeruginosa, S. aureus, E. coli, K. pneumoniae. After the } \\
\text { overnight incubation the flasks were flushed with high-grade nitrogen } \\
(3000 \mathrm{~mL} \text { over } 15 \mathrm{~min}) \text {. Identification of the species is possible as well as } \\
\text { methicillin-susceptible/resistant S. aureus strains. }\end{array}$ \\
\hline Karami et al. [87], 2017 & GC-MS & $\begin{array}{l}18 \text { ( } 2 \text { medium used, } \\
3 \text { time points, } 3 \text { organisms })\end{array}$ & $\begin{array}{l}24 \mathrm{~h} \text { in nutrient agar, subcultured at } 37^{\circ} \mathrm{C} \text { in } \\
\text { two different broth medium-Muller Hinton } \\
\text { Broth and tryptic soy broth. }\end{array}$ & $\begin{array}{l}\text { Identifying VOCs of E. coli, Candida albicans, S. aureus from cultures. } \\
\text { For headspace extraction cultures placed on a magnetic stirrer hotplate at } \\
70^{\circ} \mathrm{C} \text {. Headspace extracted using SPME at 2, } 4 \text { and } 24 \mathrm{~h} \text {. }\end{array}$ \\
\hline Ratiu et al. [91], 2017 & $\begin{array}{l}\text { ChemPro-100i (Environics } \\
\text { Oy, Finland)and TD-GC-MS } \\
\text { (for confirmation) }\end{array}$ & $\begin{array}{l}90 \text { ( } 3 \text { replicates at } \\
3 \text { time points for each of the } \\
10 \text { cultures) and } \\
30 \text { for confirmation }\end{array}$ & $\begin{array}{l}\text { Agar growth medium, } 30^{\circ} \mathrm{C} \text { for B. subtilis and } \\
\text { S. aureus and } 37^{\circ} \mathrm{C} \text { for E. coli }\end{array}$ & $\begin{array}{l}540 \text { headspace samples were analysed ( } 270 \text { from bacteria and } 270 \text { blanks with } \\
\text { medium only). Discrimination between blanks and culture, the three species: } \\
\text { E. coli, Bacillus subtilis and S. aureus and the different time points ( } 24,48 \text { and } \\
72 \mathrm{~h} \text { ) was possible. A list of VOC identified with TD-GC-MS is also shown. }\end{array}$ \\
\hline DeJong et al. [92], 2017 & $\begin{array}{l}\text { Surface enhanced } \\
\text { Raman spectroscopy }\end{array}$ & 3 Strains & $\begin{array}{l}\text { Liquid Culture in Tryptic Soy Broth } \\
\text { Soybean-Casein Digest medium for } 16 \mathrm{~h} \text { at } \\
37^{\circ} \mathrm{C} \text { transferred to agar-coated plates (Tryptic } \\
\text { Soy Agar Soybean-casein Digest). } \\
\text { SERS substrate was added. }\end{array}$ & $\begin{array}{l}\text { The technique was applied to both cultures and simulated urine and blood } \\
\text { infections with discrimination possible after } 16 \mathrm{~h} \text {. }\end{array}$ \\
\hline Rees et al. [93], 2018 & GCxGC-TOF-MS & $\begin{array}{l}100 \text { clinical isolates } \\
\text { (blood/urine) }\end{array}$ & $\begin{array}{l}37^{\circ} \mathrm{C} 200 \mathrm{rpm} \text { shaking overnight in Difco } \\
\text { Mueller-Hinston Broth (pre-culture) and 1:1000 } \\
\text { same conditions for } 12 \mathrm{~h} \text {. }\end{array}$ & $\begin{array}{l}\text { Prior to headspace analysis: } 60 \mathrm{~min} \text { at } 37^{\circ} \mathrm{C}, 200 \mathrm{rpm} \text {. Discrimination between } \\
\text { the most common infectious pathogens in blood and urine (E. coli, } \\
\text { Klebsiella species, P. aeruginosa, P. mirabilis, S. aureus, coagulase-negative } \\
\text { Staphylococcus, Acinetobacter species, Candida species, Enterobacter spp, } \\
\text { Enterococcus spp,.) was possible with a } 95 \% \text { accuracy using machine learning } \\
\text { (random forest) on } 203 \text { VOCs or } 96 \% \text { accuracy with } 811 \text { VOCs. }\end{array}$ \\
\hline Smart et al. [89], 2019 & TD-GC-MS & $\begin{array}{l}86 \text { chromatograms, } \\
18 \text { bacterial isolates }\end{array}$ & $\begin{array}{l}\text { Overnight cultures, shaking at } 180 \mathrm{rpm}, 37^{\circ} \mathrm{C} \text {. } \\
\text { Subcultures grown for } 3 \mathrm{~h} \text {. Antibiotics } \\
\text { (cephalexin or ciprofloxacin) added after } 2.5 \mathrm{~h} \text {. }\end{array}$ & $\begin{array}{l}\text { Bacteria: E. coli, K. pneumoniae, P. aeruginosa. Cultures grown in the presence of } \\
\text { cephalexin or ciprofloxacin before headspace analysis. Difference in VOC } \\
\text { profile was found between resistant and sensitive bacteria }\end{array}$ \\
\hline Adebiyi et al. [90], 2019 & $\begin{array}{l}\text { IBM Electronic } \\
\text { Volatile Analyzer }\end{array}$ & - & 5 -day culture in normal human urine at $37^{\circ} \mathrm{C}$ & $\begin{array}{c}\text { Concentration of bacteria } 1 \times 10^{9} \mathrm{CFU} / \mathrm{mL} \text {. Incubated at } 37^{\circ} \mathrm{C} \text { during } \\
\text { sampling. Different models (LR, SVM, RF, MLP) had different accuracy } \\
\text { (overall, } 90 \%>\text { and some had } 100 \% \text { ) }\end{array}$ \\
\hline
\end{tabular}




\section{Discussion and Conclusions}

UTI diagnosis has not changed for over 10 years and is not reflective of the currently available methods and technologies. There is a clear need for a more accurate and rapid test, which is economically feasible. Several research teams across the world are working on better ways to diagnose UTI in the pursuit of the $£ 8 \mathrm{~m}$ Longitude prize [131], an inducement prize contest by the UK-based charity NESTA (National Endowment for Science, Technology and the Arts), incentivising the development of an affordable, accurate, and fast point-of-care test for bacterial infection. This competition highlights both the clinical demand for a new diagnostic tool and the growing research interest in the field.

There are several challenges associated with UTI diagnosis based on VOC analysis. While GC-MS is considered the gold standard [132], this method is expensive, time-consuming and requires highly-trained operators [133]. This also applies to other technologies, such as PTR-MS and SIFT-MS. Most analytical platforms are not portable and therefore unsuitable for point-of-care applications. As a result, urine samples need to be stored and transported from a clinical to a laboratory setting. Thereafter, the urine sample often still has to be cultured (3.5-6 h). Further delays might be incurred between generating results and reporting these to the clinician. Even once the sample has been analysed and results are available, they are unlikely to be definitive, since VOCs are not always specific to a single species. Some of these delays could be reduced by utilising eNose and/or IMS technologies, which are suitable for direct analysis and can be used in a clinical setting. Other challenges associated with urine VOC analysis are more fundamental. While urine analysis is the third major diagnostic screening test in clinical laboratories, there is a lack of well-established and standardised methods regarding procedures for collection, transportation, sample preparation and analysis [134]. During sample collection, patients suspected for UTI are instructed to deliver a mid-stream urine (MSU) sample, by voiding firstly into the toilet and secondly into a urine container. MSU samples are associated with significantly higher bacterial levels than first-voided urine samples [135]. However, instructing a patient in MSU collection can be time-consuming, challenging, and can introduce bias due to incorrectly collected samples [136]. In addition to this, urine is susceptible to other confounding factors, such as dietary intake, diuresis and exercise [137], as well as intake of prescription and non-prescription medication and supplements [138]. Further difficulties are experienced during sample storage and transport. Once the sample has been provided, it is essential for the sample to be frozen immediately, or at least chilled. If the sample is left at room temperature beyond four hours before analysis, it may lead to increased numbers of colony forming units (CFU) being interpreted as significant growth [136]. The samples also need to remain frozen during transport, which can impose logistical challenges for both in-house and external sample transportation. A common solution to this is using dry ice, since it has little effect on the samples for short transport periods [139]. The age of the sample should also be considered [140]. Improper storage can lower the quality/performance of the urinary test [137]. In regard to sample preparation, various methods have been used to defrost samples. For example, frozen samples might be stored at $-80{ }^{\circ} \mathrm{C}$ and thawed at room temperature [141] or stored at $-20^{\circ} \mathrm{C}$ and defrosted by immersing the vial in a water bath at $60^{\circ} \mathrm{C}$ for $30 \mathrm{~s}$ [24]. Once the samples have been defrosted, an aliquot of the sample is transferred into a vial. The analysed urine volume, per sample, varies significantly across urine VOC studies, e.g., $0.75-8 \mathrm{~mL}[24,42,134,142]$. If headspace analysis is to be performed, the temperature of the sample is commonly elevated, to increase the sample vapour pressure [143]. The duration and temperatures for this procedure vary across studies, e.g., 5-20 min and 37-90 ${ }^{\circ} \mathrm{C}[42,144-146]$. Lastly, while urine constitutes a highly complex and rich source of analytes, headspace gas samples are unlikely to represent the full metabolite content of the medium. Method development studies are therefore necessary to determine what procedures should be applied in order to demonstrate the full potential of urine analysis for UTI diagnosis. Some challenges associated with sample preparation and analysis have been improved through the use of auto-samplers, which have enhanced the accuracy, repeatability, and productivity of urine analysis [137]. Optimised sampling and analysis conditions for VOCs in urine headspace analysis should be investigated, as has been done 
for faecal samples [147]. This could significantly improve the clinical applicability of such methods, in order to gain wide-spread use.

Despite the challenges, there are promising developments in the field of VOC analysis, which indicate that this method has great potential to aid in the diagnosis of bacterial infection in the future. The continuous drive for miniaturisation, portability, high-throughput and rapid analysis is likely to produce a wide range of eNose and IMS designs which will offer great potential for a large diversity of detection capabilities [148-150]. Moreover, as sensing technologies continue to advance, a greater number of VOCs are likely to be detectable at lower concentrations [151]. The progress that has been made in recent decades was illustrated in a meta-analysis, using machine learning on the VOCs emitted by human microbial pathogens, extracted from papers published between 1977 and 2016. The analysis showed that a set of 18 VOCs was sufficient to distinguish between 11 different infectious agents, with an accuracy of 77\% [152]. This suggests that the fundamental potential of using VOCs for diagnosing bacterial infections has been successfully demonstrated. Further work is required to build an extensive library of reliable VOC profiles, across different analytical platforms, which correspond with UTI pathogens.

Some of the papers presented in this review cultured the sample/pathogens for a short period of time. The use of direct analysis is associated with decreased sensitivity and specificity, since urine varies drastically across individuals and even in the same person at different collection times (affected by digestion of food, level of hydration and lifestyle [153-156]). However, even if the specificity and sensitivity were to be decreased by $10-15 \%$, these results would be comparable to the urine dipstick test results, while providing crucial insight for the patient, since a targeted course of antibiotics could be started immediately.

Following GC-MS methods, eNose and IMS technologies were evaluated for the diagnosis of UTI. A common criticism of eNose and IMS technology is that they are unable to determine the identity and concentration of individual VOCs, except for combined-technology instruments [60]. It has therefore been argued that this "black box" approach relies too heavily on pattern-recognition algorithms [157]. Moreover, this method cannot yield a targeted VOC biomarker test for the diagnosis of a particular condition or disease [158]. In this case, it is true that the eNose approach cannot identify unique biomarkers for UTI. However, it should be noted that unique biomarkers do not necessarily exist for individual UTI pathogens and that even if they did, they would be included as a constituent of the overall pattern analysed by the algorithms. Furthermore, as indicated in this review, pattern recognition has already demonstrated potential in determining the status of a sample and recognised the relevant pathogen, without VOC identification. Another disadvantage associated with eNoses is that, compared to classic culture, there is a lack of antibiotic resistance data. In future, it may be possible to use eNoses on urine samples, with antibiotics added to them for a period of time, to identify if a strain is susceptible or resistant. This information could drastically reduce the test time, from the current standard of 24-72 h. If this is not feasible, local antibiotic resistance profiles and data from clinical laboratories could be used to make predictions and recommendations for appropriate treatments, once a pathogen has been identified in a urine sample. Moreover, the classification of growth phase is possible and this can be used to calibrate the antibiotic dosage for treatment [129].

For VOC detection of UTIs to become routine in clinical use, a number of hurdles need to be overcome. For example, more information regarding bacterial VOCs and data analysis models are required. Moreover, clinical staff need to be educated about VOC urine headspace analysis, taught how to interpret results and receive training on how to use the relevant equipment. An advantage of eNoses and IMS systems is that they are relatively user-friendly. While eNoses do not recognise specific VOCs, the sensors can be chosen to respond to specific chemical classes, which could increase the accuracy of detection. This emphasises that some prior information regarding the VOCs of the urinary pathogens is required, even for eNose analysis. One of the advantages of eNoses is also considered a drawback for expanding the use of the technology - the versatility of devices makes it challenging to establish a standard. Since research groups all over the world are developing different types of 
eNoses (MOS, QMB, or CP-based), it is unclear which one should be routinely used for UTI VOC detection. A standard, commercially available, and CE-marked device would increase the probability of wide-spread use by clinics and laboratories. Currently, the hardware used for detection, as well as the software required for data analysis, is advanced enough to identify infected urine samples, the pathogen and possibly its susceptibility to antibiotics. Since eNoses can be used in point-of-care applications (e.g, bedside testing), with automated analysis and delivering results minutes after sample collection, they have significant potential to serve as a clinical diagnostic tool for UTI. Furthermore, the information provided by eNoses is objective and less prone to contamination during collection or handling steps.

One of the key challenges associated with diagnosing UTI is that symptoms may overlap with other conditions, such as haematuria-one of the most common signs of bladder cancer. In addition, patients with asymptomatic bacteriuria may not benefit from treatment. However, distinguishing it from UTI is often subjective, as what is classified as asymptomatic could be problematic when patients with catheters or defects of the bladder (neurological or anatomical) are taken into consideration [25]. Catheters are a risk factor for UTI and catheter-associated urinary tract infection (CAUTI) is the most common nosocomial infection worldwide [159]. This highlights the need for an accurate and objective test. Further investigations are necessary to analyse whether VOC analysis could be used for this application.

There are also other potential applications. For example, during pregnancy, a patient with UTI can show no symptoms, i.e., the usual signs, such as pain and burning sensation, might be absent. Cases of UTIs during pregnancy, even when asymptomatic, have been linked with preterm delivery, intrauterine growth retardation, low birth weight, maternal hypertension, pre-eclampsia, and anaemia [160]. The application of eNoses would be optimal for the routine testing of urine, e.g., during antenatal appointments. This could provide an effective method of detecting asymptomatic UTI during pregnancy.

Currently, the aim of deploying these technologies is not to replace the existing methods. Instead, they are intended to complement the diagnostic process, by aiding clinicians and medics to make better and faster decisions. The recent developments in technology, making the devices portable, accessible for point-of-care, automation of data analysis, and overall ease of use, facilitates VOC detection for routine clinical testing. Both metabolite detection and sensor-based techniques, together with pattern recognition, provide a powerful tool for diagnosis. Further studies are required to investigate the ability of eNoses to distinguish between resistant and susceptible bacterial strains. All medical devices must go through clinical trials. As such, eNoses need to be registered, verified, and validated before they can be accepted for routine clinical use.

\section{Methods}

An electronic search was performed using GoogleScholar and PubMed databases. The search terms volatile organic compounds (VOCs), urinary tract infection (UTI), microbial, pathogen, and bacteria were used in combination with the Boolean operators AND and OR. Additional searches were conducted including common bacterial pathogens (e.g., UroPathogenic Escherichia coli and Klebsiella pneumoniae) and analytical platforms (e.g., electronic nose (eNose) and gas chromatography mass spectrometry (GC-MS)). Articles were selected for full-text examination based on the relevance of the title and abstract. In the initial screening 65 articles were selected, further searches and references in the initial articles resulted in selecting another 79 articles for full-text examination. From the investigated articles, 45 were included in this review, and 27 of those are incorporated in Table 3. Compounds found in the literature (23 articles) are summarised in Table 2, divided by chemical classification (compounds were only included once in the most relevant category). Nine articles that analysed pathogens isolated from a different location (lungs/blood) or grown in blood culture were also included to illustrate that the same VOCs are bacteria-related rather than location/media dependent. Either of the following criteria had to be met in order to be included in the review: (1) VOC analysis was used to discriminate 
infected urine samples (clinical or simulated) or (2) VOCs were used to examine a pathogen that could cause UTIs. Multiple publications of the same data were excluded.

Author Contributions: J.A.C. conceptualised the project and supervised its progress. Original draft preparation was conducted by V.-M.D. Review and editing of the manuscript were completed by V.-M.D., A.T. and J.A.C. All authors have read and agreed to the published version of the manuscript.

Funding: V.-M.D. is funded by the Medical Research Council through the University of Warwick Doctoral Training Partnership, grant number MR/N014294/1.

Conflicts of Interest: The authors declare no conflict of interest.

\section{References}

1. Flores-Mireles, A.L.; Walker, J.N.; Caparon, M.; Hultgren, S.J. Urinary tract infections: Epidemiology, mechanisms of infection and treatment options. Nat. Rev. Microbiol. 2015, 13, 269-284. [CrossRef] [PubMed]

2. Tan, C.W.; Chlebicki, M.P. Urinary tract infections in adults. Singap. Med. J. 2016, 57, 485-490. [CrossRef] [PubMed]

3. Ellis, A.K.; Verma, S. Quality of Life in Women with Urinary Tract Infections: Is Benign Disease a Misnomer? J. Am. Board Fam. Med. 2000, 13, 392-397. [CrossRef] [PubMed]

4. Beahm, N.P.; Nicolle, L.E.; Bursey, A.; Smyth, D.J.; Tsuyuki, R.T. The assessment and management of urinary tract infections in adults: Guidelines for pharmacists. Can. Pharm. J. Rev. Pharm. Can. 2017, 150, 298-305. [CrossRef] [PubMed]

5. Griebling, T.L. Urologic diseases in America project: Trends in resource use for urinary tract infections in women. J. Urol. 2005, 173, 1288-1294. [CrossRef] [PubMed]

6. Renard, J.; Ballarini, S.; Mascarenhas, T.; Zahran, M.; Quimper, E.; Choucair, J.; Iselin, C.E. Recurrent Lower Urinary Tract Infections Have a Detrimental Effect on Patient Quality of Life: A Prospective, Observational Study. Infect. Dis. Ther. 2015, 4, 125-135. [CrossRef] [PubMed]

7. Najeeb, S.; Munir, T.; Rehman, S.; Hafiz, A.; Gilani, M.; Latif, M. Comparison of Urine Dipstick Test with Conventional Urine Culture in Diagnosis of Urinary Tract Infection. J. Coll. Physicians Surg. 2015, 25, 108-110.

8. Simon, M.G.; Davis, C.E. Instrumentation and sensors for human breath analysis. In Advances in Biomedical Sensing, Measurements, Instrumentation and Systems; Mukhopadhyay, S.C., Lay-Ekuakille, A., Eds.; Lecture Notes in Electrical Engineering; Springer: Berlin/Heidelberg, Germany, 2010; Volume 55, pp. 144-165, ISBN 978-3-642-05166-1.

9. Porter, R. The early years. In The Greatest Benefit to Mankind: A Medical History of Humanity from Antiquity to the Present; Harper Collins: London, UK, 1999; pp. 147-162, ISBN 978-0-00-637454-1.

10. Wilson, A.D.; Baietto, M. Advances in Electronic-Nose Technologies Developed for Biomedical Applications. Sensors 2011, 11, 1105-1176. [CrossRef]

11. Williams, H.; Pembroke, A. Sniffer Dogs in the Melanoma Clinic? Lancet 1989, 333, 734. [CrossRef]

12. Willis, C.M.; Church, S.M.; Guest, C.M.; Cook, W.A.; McCarthy, N.; Bransbury, A.J.; Church, M.R.T.; Church, J.C.T. Olfactory detection of human bladder cancer by dogs: Proof of principle study. BMJ 2004, 329, 712. [CrossRef]

13. McCulloch, M.; Turner, K.; Broffman, M. Lung cancer detection by canine scent: Will there be a lab in the lab? Eur. Respir. J. 2012, 39, 511-512. [CrossRef] [PubMed]

14. McCulloch, M.; Jezierski, T.; Broffman, M.; Hubbard, A.; Turner, K.; Janecki, T. Diagnostic Accuracy of Canine Scent Detection in Early- and Late-Stage Lung and Breast Cancers. Integr. Cancer Ther. 2006, 5, 30-39. [CrossRef] [PubMed]

15. Cornu, J.-N.; Cancel-Tassin, G.; Ondet, V.; Girardet, C.; Cussenot, O. Olfactory Detection of Prostate Cancer by Dogs Sniffing Urine: A Step Forward in Early Diagnosis. Eur. Urol. 2011, 59, 197-201. [CrossRef] [PubMed]

16. Horvath, G.; Järverud, G.A.K.; Järverud, S.; Horváth, I. Human Ovarian Carcinomas Detected by Specific Odor. Integr. Cancer Ther. 2008, 7, 76-80. [CrossRef]

17. Van Oort, P.M.; Povoa, P.; Schnabel, R.; Dark, P.; Artigas, A.; Bergmans, D.C.J.J.; Felton, T.; Coelho, L.; Schultz, M.J.; Fowler, S.J.; et al. The potential role of exhaled breath analysis in the diagnostic process of pneumonia-a systematic review. J. Breath Res. 2018, 12, 024001. [CrossRef] 
18. Gao, Q.; Lee, W.-Y. Urinary Metabolites for Urological Cancer Detection: A Review on the Application of Volatile Organic Compounds for Cancers. Am. J. Clin. Exp. Urol. 2019, 7, 232.

19. Silva, C.L.; Passos, M.; Câmara, J.S. Solid phase microextraction, mass spectrometry and metabolomic approaches for detection of potential urinary cancer biomarkers-A powerful strategy for breast cancer diagnosis. Talanta 2012, 89, 360-368. [CrossRef]

20. Sethi, S.; Nanda, R.; Chakraborty, T. Clinical Application of Volatile Organic Compound Analysis for Detecting Infectious Diseases. Clin. Microbiol. Rev. 2013, 26, 462-475. [CrossRef]

21. Banday, K.M.; Pasikanti, K.K.; Chan, E.C.Y.; Singla, R.; Rao, K.V.S.; Chauhan, V.S.; Nanda, R.K. Use of Urine Volatile Organic Compounds to Discriminate Tuberculosis Patients from Healthy Subjects. Anal. Chem. 2011, 83, 5526-5534. [CrossRef]

22. Monteiro, M.; Carvalho, M.; Henrique, R.; Jerónimo, C.; Moreira, N.; De Lourdes Bastos, M.; De Pinho, P.G. Analysis of volatile human urinary metabolome by solid-phase microextraction in combination with gas chromatography-mass spectrometry for biomarker discovery: Application in a pilot study to discriminate patients with renal cell carcinoma. Eur. J. Cancer 2014, 50, 1993-2002. [CrossRef]

23. Weber, C.M.; Cauchi, M.; Patel, M.; Bessant, C.; Turner, C.; Britton, L.E.; Willis, C.M. Evaluation of a gas sensor array and pattern recognition for the identification of bladder cancer from urine headspace. Analyst 2011, 136, 359-364. [CrossRef]

24. Khalid, T.; Aggio, R.; White, P.; De Lacy Costello, B.; Persad, R.; Al-Kateb, H.; Jones, P.; Probert, C.S.; Ratcliffe, N. Urinary Volatile Organic Compounds for the Detection of Prostate Cancer. PLoS ONE 2015, 10, e0143283. [CrossRef] [PubMed]

25. Mach, K.E.; Wong, P.K.; Liao, J.C. Biosensor diagnosis of urinary tract infections: A path to better treatment? Trends Pharmacol. Sci. 2011, 32, 330-336. [CrossRef] [PubMed]

26. Foxman, B. The epidemiology of urinary tract infection. Nat. Rev. Urol. 2010, 7, 653-660. [CrossRef] [PubMed]

27. Hooton, T.M. Uncomplicated Urinary Tract Infection. N. Engl. J. Med. 2012, 366, 1028-1037. [CrossRef] [PubMed]

28. Nicolle, L. Complicated Urinary Tract Infection in Adults. Can. J. Infect. Dis. Med. Microbiol. 2005, 16, 349-360. [CrossRef] [PubMed]

29. Seymour, C.W.; Gesten, F.; Prescott, H.C.; Friedrich, M.E.; Iwashyna, T.J.; Phillips, G.S.; Lemeshow, S.; Osborn, T.; Terry, K.M.; Levy, M.M. Time to Treatment and Mortality during Mandated Emergency Care for Sepsis. N. Engl. J. Med. 2017, 376, 2235-2244. [CrossRef]

30. Hatfield, K.M.; Dantes, R.B.; Baggs, J.; Sapiano, M.R.P.; Fiore, A.E.; Jernigan, J.A.; Epstein, L. Assessing Variability in Hospital-Level Mortality Among, U.S. Medicare Beneficiaries with Hospitalizations for Severe Sepsis and Septic Shock. Crit. Care Med. 2018, 46, 1753-1760. [CrossRef]

31. François, M.; Hanslik, T.; Dervaux, B.; Le Strat, Y.; Souty, C.; Vaux, S.; Maugat, S.; Rondet, C.; Sarazin, M.; Heym, B.; et al. The economic burden of urinary tract infections in women visiting general practices in France: A cross-sectional survey. BMC Health Serv. Res. 2016, 16, 365. [CrossRef]

32. Bhalodi, A.A.; Van Engelen, T.S.R.; Virk, H.S.; Wiersinga, W.J. Impact of antimicrobial therapy on the gut microbiome. J. Antimicrob. Chemother. 2019, 74, i6-i15. [CrossRef]

33. O'Neill, J. Antimicrobial Resistance: Tackling a Crisis for the Health and Wealth of Nations; Wellcome Trust: London, UK, 2014; pp. 1-20.

34. Zowawi, H.M.; Harris, P.N.A.; Roberts, M.J.; Tambyah, P.A.; Schembri, M.A.; Pezzani, M.D.; Williamson, D.A.; Paterson, D.L. The emerging threat of multidrug-resistant Gram-negative bacteria in urology. Nat. Rev. Urol. 2015, 12, 570-584. [CrossRef] [PubMed]

35. Spees, A.M.; Wangdi, T.; Lopez, C.A.; Kingsbury, D.D.; Xavier, M.N.; Winter, S.E.; Tsolis, R.M.; Bäumler, A.J. Streptomycin-Induced Inflammation Enhances Escherichia coli Gut Colonization Through Nitrate Respiration. mBio 2013, 4, e00430-13. [CrossRef] [PubMed]

36. Hay, A.D.; Birnie, K.; Busby, J.; Delaney, B.; Downing, H.; Dudley, J.; Durbaba, S.; Fletcher, M.; Harman, K.; Hollingworth, W.; et al. The Diagnosis of Urinary Tract infection in Young children (DUTY): A diagnostic prospective observational study to derive and validate a clinical algorithm for the diagnosis of urinary tract infection in children presenting to primary care with an acute illness. Health Technol. Assess. 2016, 20, 1-294. [CrossRef] [PubMed] 
37. Devillé, W.L.; Yzermans, J.C.; van Duijn, N.P.; Bezemer, P.D.; van der Windt, D.A.; Bouter, L.M. The urine dipstick test useful to rule out infections. A meta-analysis of the accuracy. BMC Urol. 2004, 4, 4. [CrossRef]

38. Bent, S. Does This Woman Have an Acute Uncomplicated Urinary Tract Infection? JAMA 2002, $287,2701$. [CrossRef]

39. Beale, D.; Jones, O.; Karpe, A.; Dayalan, S.; Oh, D.; Kouremenos, K.; Ahmed, W.; Palombo, E. A Review of Analytical Techniques and Their Application in Disease Diagnosis in Breathomics and Salivaomics Research. Int. J. Mol. Sci. 2016, 18, 24. [CrossRef]

40. Xu, M.; Tang, Z.; Duan, Y.; Liu, Y. GC-Based Techniques for Breath Analysis: Current Status, Challenges, and Prospects. Crit. Rev. Anal. Chem. 2016, 46, 291-304. [CrossRef]

41. Covington, J.A.; Van der Schee, M.P.; Edge, A.S.L.; Boyle, B.; Savage, R.S.; Arasaradnam, R.P. The application of FAIMS gas analysis in medical diagnostics. Analyst 2015, 140, 6775-6781. [CrossRef]

42. Arasaradnam, R.P.; McFarlane, M.J.; Ryan-Fisher, C.; Westenbrink, E.; Hodges, P.; Thomas, M.G.; Chambers, S.; O'Connell, N.; Bailey, C.; Harmston, C.; et al. Detection of Colorectal Cancer (CRC) by Urinary Volatile Organic Compound Analysis. PLoS ONE 2014, 9, e108750. [CrossRef]

43. Westhoff, M.; Litterst, P.; Maddula, S.; Bödeker, B.; Rahmann, S.; Davies, A.N.; Baumbach, J.I. Differentiation of chronic obstructive pulmonary disease (COPD) including lung cancer from healthy control group by breath analysis using ion mobility spectrometry. Int. J. Ion. Mobil. Spectrom. 2010, 13, 131-139. [CrossRef]

44. Wilson, A.D. Applications of Electronic-Nose Technologies for Noninvasive Early Detection of Plant, Animal and Human Diseases. Chemosensors 2018, 6, 45. [CrossRef]

45. Madrolle, S.; Grangeat, P.; Jutten, C. A Linear-Quadratic Model for the Quantification of a Mixture of Two Diluted Gases with a Single Metal Oxide Sensor. Sensors 2018, 18, 1785. [CrossRef] [PubMed]

46. Szulczyński, B.; Gębicki, J. Currently Commercially Available Chemical Sensors Employed for Detection of Volatile Organic Compounds in Outdoor and Indoor Air. Environments 2017, 4, 21. [CrossRef]

47. Persaud, K.C. Polymers for chemical sensing. Mater. Today 2005, 8, 38-44. [CrossRef]

48. Kim, Y.S.; Ha, S.-C.; Yang, Y.; Kim, Y.J.; Cho, S.M.; Yang, H.; Kim, Y.T. Portable electronic nose system based on the carbon black-polymer composite sensor array. Sens. Actuators B Chem. 2005, 108, 285-291. [CrossRef]

49. Nakhleh, M.K.; Broza, Y.Y.; Haick, H. Monolayer-capped gold nanoparticles for disease detection from breath. Nanomedicine 2014, 9, 1991-2002. [CrossRef]

50. Tisch, U.; Haick, H. Arrays of chemisensitive monolayer-capped metallic nanoparticles for diagnostic breath testing. Rev. Chem. Eng. 2010, 26. [CrossRef]

51. Fernandes, M.P.; Venkatesh, S.; Sudarshan, B.G. Early Detection of Lung Cancer Using Nano-Nose-A Review. Open Biomed. Eng. J. 2015, 9, 228-233. [CrossRef]

52. Wang, S.; Inci, F.; De Libero, G.; Singhal, A.; Demirci, U. Point-of-care assays for tuberculosis: Role of nanotechnology/microfluidics. Biotechnol. Adv. 2013, 31, 438-449. [CrossRef]

53. Liu, X.; Cheng, S.; Liu, H.; Hu, S.; Zhang, D.; Ning, H. A Survey on Gas Sensing Technology. Sensors 2012, 12, 9635-9665. [CrossRef]

54. Wilson, A.; Baietto, M. Applications and Advances in Electronic-Nose Technologies. Sensors 2009, 9, 5099-5148. [CrossRef] [PubMed]

55. Wilson, A. Advances in Electronic-Nose Technologies for the Detection of Volatile Biomarker Metabolites in the Human Breath. Metabolites 2015, 5, 140-163. [CrossRef] [PubMed]

56. Wilson, A.D. Review of Electronic-nose Technologies and Algorithms to Detect Hazardous Chemicals in the Environment. Procedia Technol. 2012, 1, 453-463. [CrossRef]

57. Jian, Y.; Hu, W.; Zhao, Z.; Cheng, P.; Haick, H.; Yao, M.; Wu, W. Gas Sensors Based on Chemi-Resistive Hybrid Functional Nanomaterials. Nano-Micro Lett. 2020, 12, 71. [CrossRef]

58. Korotcenkov, G.; Brinzari, V.; Cho, B.K. Conductometric gas sensors based on metal oxides modified with gold nanoparticles: A review. Microchim. Acta 2016, 183, 1033-1054. [CrossRef]

59. Westenbrink, E.; Arasaradnam, R.P.; O'Connell, N.; Bailey, C.; Nwokolo, C.; Bardhan, K.D.; Covington, J.A. Development and application of a new electronic nose instrument for the detection of colorectal cancer. Biosens. Bioelectron. 2015, 67, 733-738. [CrossRef]

60. Wilson, A. Application of Electronic-Nose Technologies and VOC-Biomarkers for the Noninvasive Early Diagnosis of Gastrointestinal Diseases. Sensors 2018, 18, 2613. [CrossRef]

61. Sohn, J.H.; Atzeni, M.; Zeller, L.; Pioggia, G. Characterisation of humidity dependence of a metal oxide semiconductor sensor array using partial least squares. Sens. Actuators B Chem. 2008, 131, 230-235. [CrossRef] 
62. Fryder, M.; Holmberg, M.; Winquist, F.; Lundstrom, I. A calibration technique for an electronic nose. In Proceedings of the International Solid-State Sensors and Actuators Conference-TRANSDUCERS'95, Stockholm, Sweden, 25-29 June 1995; IEEE: Piscataway, NJ, USA, 1995; Volume 1, pp. 683-686.

63. Lechner, M.; Karlseder, A.; Niederseer, D.; Lirk, P.; Neher, A.; Rieder, J.; Tilg, H.H. pylori Infection Increases Levels of Exhaled Nitrate. Helicobacter 2005, 10, 385-390. [CrossRef]

64. Zhan, X.; Duan, J.; Duan, Y. Recent developments of proton-transfer reaction mass spectrometry (PTR-MS) and its applications in medical research. Mass Spectrom. Rev. 2013, 32, 143-165. [CrossRef]

65. Blake, G.J.; Otvos, J.D.; Rifai, N.; Ridker, P.M. Low-Density Lipoprotein Particle Concentration and Size as Determined by Nuclear Magnetic Resonance Spectroscopy as Predictors of Cardiovascular Disease in Women. Circulation 2002, 106, 1930-1937. [CrossRef] [PubMed]

66. Moka, D.; Vorreuther, R.; Schicha, H.; Spraul, M.; Humpfer, E.; Lipinski, M.; Foxall, P.J.D.; Nicholson, J.K.; Lindon, J.C. Biochemical classification of kidney carcinoma biopsy samples using magic-angle-spinning $1 \mathrm{H}$ nuclear magnetic resonance spectroscopy. J. Pharm. Biomed. Anal. 1998, 17, 125-132. [CrossRef]

67. Shulman, G.I.; Alger, J.R.; Prichard, J.W.; Shulman, R.G. Nuclear magnetic resonance spectroscopy in diagnostic and investigative medicine. J. Clin. Investig. 1984, 74, 1127-1131. [CrossRef] [PubMed]

68. Bajtarevic, A.; Ager, C.; Pienz, M.; Klieber, M.; Schwarz, K.; Ligor, M.; Ligor, T.; Filipiak, W.; Denz, H.; Fiegl, M.; et al. Noninvasive detection of lung cancer by analysis of exhaled breath. BMC Cancer 2009, 9, 348. [CrossRef] [PubMed]

69. Wlodzimirow, K.A.; Abu-Hanna, A.; Schultz, M.J.; Maas, M.A.W.; Bos, L.D.J.; Sterk, P.J.; Knobel, H.H.; Soers, R.J.T.; Chamuleau, R.A.F.M. Exhaled breath analysis with electronic nose technology for detection of acute liver failure in rats. Biosens. Bioelectron. 2014, 53, 129-134. [CrossRef] [PubMed]

70. Smolinska, A.; Hauschild, A.-C.; Fijten, R.R.R.; Dallinga, J.W.; Baumbach, J.; Van Schooten, F.J. Current breathomics-A review on data pre-processing techniques and machine learning in metabolomics breath analysis. J. Breath Res. 2014, 8, 027105. [CrossRef]

71. Pereira, J.; Porto-Figueira, P.; Cavaco, C.; Taunk, K.; Rapole, S.; Dhakne, R.; Nagarajaram, H.; Câmara, J. Breath Analysis as a Potential and Non-Invasive Frontier in Disease Diagnosis: An Overview. Metabolites 2015, 5, 3-55. [CrossRef]

72. Guyon, I.; Elisseff, A. An introduction to variable and feature selection. J. Mach. Learn. Res. 2003, 3, 1157-1182.

73. Woollam, M.; Teli, M.; Liu, S.; Daneshkhah, A.; Siegel, A.P.; Yokota, H.; Agarwal, M. Urinary Volatile Terpenes Analyzed by Gas Chromatography-Mass Spectrometry to Monitor Breast Cancer Treatment Efficacy in Mice. J. Proteome Res. 2020, 19, 1913-1922. [CrossRef]

74. Mozdiak, E.; Wicaksono, A.N.; Covington, J.A.; Arasaradnam, R.P. Colorectal cancer and adenoma screening using urinary volatile organic compound (VOC) detection: Early results from a single-centre bowel screening population (UK BCSP). Tech. Coloproctol. 2019, 23, 343-351. [CrossRef]

75. Mazzone, P.J.; Wang, X.-F.; Lim, S.; Choi, H.; Jett, J.; Vachani, A.; Zhang, Q.; Beukemann, M.; Seeley, M.; Martino, R.; et al. Accuracy of volatile urine biomarkers for the detection and characterization of lung cancer. BMC Cancer 2015, 15, 1001. [CrossRef] [PubMed]

76. Matsumura, K.; Opiekun, M.; Oka, H.; Vachani, A.; Albelda, S.M.; Yamazaki, K.; Beauchamp, G.K. Urinary Volatile Compounds as Biomarkers for Lung Cancer: A Proof of Principle Study Using Odor Signatures in Mouse Models of Lung Cancer. PLoS ONE 2010, 5, e8819. [CrossRef] [PubMed]

77. Hayward, N.J.; Jeavons, T.H.; Nicholson, A.J.; Thornton, A.G. Methyl mercaptan and dimethyl disulfide production from methionine by Proteus species detected by head-space gas-liquid chromatography. J. Clin. Microbiol. 1977, 6, 187-194. [PubMed]

78. Hayward, N.J.; Jeavons, T.H.; Nicholson, A.J.; Thornton, A.G. Development of specific tests for rapid detection of Escherichia coli and all species of Proteus in urine. J. Clin. Microbiol. 1977, 6, 195-201.

79. Hayward, N.J.; Jeavons, T.H. Assessment of Technique for Rapid Detection of Escherichia Coli and Proteus Species in Urine by Head-Space Gas-Liquid Chromatography. J. Clin. Microbiol. 1977, 6, 202-208.

80. Coloe, P.J. Ethanol formed from arabinose: A rapid method for detecting Escherichia coli. J. Clin. Pathol. 1978, 31, 361-364. [CrossRef]

81. Coloe, P.J. Head-space gas liquid chromatography for rapid detection of Escherichia coli and Proteus mirabilis in urine. J. Clin. Pathol. 1978, 31, 365-369. [CrossRef]

82. Manja, K.S.; Rao, K.M. Gas-chromatographic detection of urinary tract infections caused by Escherichia coli and Klebsiella sp. J. Clin. Microbiol. 1983, 17, 264-266. [CrossRef] 
83. Davies, T.J.; Hayward, N.J. Volatile products from acetylcholine as markers in the rapid urine test using head-space gas-liquid chromatography. J. Chromatogr. B Biomed. Sci. Appl. 1984, 307, 11-21. [CrossRef]

84. Storer, M.K.; Hibbard-Melles, K.; Davis, B.; Scotter, J. Detection of volatile compounds produced by microbial growth in urine by selected ion flow tube mass spectrometry (SIFT-MS). J. Microbiol. Methods 2011, 87, 111-113. [CrossRef]

85. Thorn, R.M.S.; Reynolds, D.M.; Greenman, J. Multivariate analysis of bacterial volatile compound profiles for discrimination between selected species and strains in vitro. J. Microbiol. Methods 2011, 84, 258-264. [CrossRef] [PubMed]

86. Bean, H.D.; Dimandja, J.-M.D.; Hill, J.E. Bacterial volatile discovery using solid phase microextraction and comprehensive two-dimensional gas chromatography-time-of-flight mass spectrometry. J. Chromatogr. B 2012, 901, 41-46. [CrossRef] [PubMed]

87. Karami, N.; Mirzajani, F.; Rezadoost, H.; Karimi, A.; Fallah, F.; Ghassempour, A.; Aliahmadi, A. Initial study of three different pathogenic microorganisms by gas chromatography-mass spectrometry. F1000Research 2018, 6, 1415. [CrossRef] [PubMed]

88. Altaee, N.; Kadhim, M.J.; Hameed, I.H. Detection of Volatile Compounds Produced by Pseudomonas aeruginosa Isolated from UTI Patients by Gas Chromatography-Mass Spectrometry. Int. J. Curr. Pharm. Rev. Res. 2017, 7, 8-24.

89. Smart, A.; De Lacy Costello, B.; White, P.; Avison, M.; Batty, C.; Turner, C.; Persad, R.; Ratcliffe, N. Sniffing out resistance-Rapid identification of urinary tract infection-causing bacteria and their antibiotic susceptibility using volatile metabolite profiles. J. Pharm. Biomed. Anal. 2019, 167, 59-65. [CrossRef] [PubMed]

90. Adebiyi, A.; Swaminathan, S.; Than, N.; Abdi, M.; Bowers, A.N.; Fasoli, A.; Mannari, A.; Bozano, L. Rapid Strain Differentiation of E. coli-inoculated Urine Using Olfactory-based Smart Sensors. Sens. Transducers 2019, 238, 94-98.

91. Ratiu, I.A.; Bocos-Bintintan, V.; Patrut, A.; Moll, V.H.; Turner, M.; Thomas, C.L.P. Discrimination of bacteria by rapid sensing their metabolic volatiles using an aspiration-type ion mobility spectrometer (a-IMS) and gas chromatography-mass spectrometry GC-MS. Anal. Chim. Acta 2017, 982, 209-217. [CrossRef]

92. DeJong, C.S.; Wang, D.I.; Polyakov, A.; Rogacs, A.; Simske, S.J.; Shkolnikov, V. Bacterial Detection and Differentiation via Direct Volatile Organic Compound Sensing with Surface Enhanced Raman Spectroscopy. ChemistrySelect 2017, 2, 8431-8435. [CrossRef]

93. Rees, C.A.; Burklund, A.; Stefanuto, P.-H.; Schwartzman, J.D.; Hill, J.E. Comprehensive volatile metabolic fingerprinting of bacterial and fungal pathogen groups. J. Breath Res. 2018, 12, 026001. [CrossRef]

94. Wiesner, K.; Jaremek, M.; Pohle, R.; Von Sicard, O.; Stuetz, E. Monitoring of Bacterial Growth and Rapid Evaluation of Antibiotic Susceptibility by Headspace Gas Analysis. Procedia Eng. 2014, 87, 332-335. [CrossRef]

95. Sovová, K.; Čepl, J.; Markoš, A.; Španěl, P. Real time monitoring of population dynamics in concurrent bacterial growth using SIFT-MS quantification of volatile metabolites. Analyst 2013, 138, 4795. [CrossRef] [PubMed]

96. Zechman, J.M.; Aldinger, S.; Labows, J.N. Characterization of pathogenic bacteria by automated headspace concentration-gas chromatography. J. Chromatogr. B Biomed. Sci. Appl. 1986, 377, 49-57. [CrossRef]

97. Luchner, M.; Gutmann, R.; Bayer, K.; Dunkl, J.; Hansel, A.; Herbig, J.; Singer, W.; Strobl, F.; Winkler, K.; Striedner, G. Implementation of proton transfer reaction-mass spectrometry (PTR-MS) for advanced bioprocess monitoring. Biotechnol. Bioeng. 2012, 109, 3059-3069. [CrossRef] [PubMed]

98. Edman, D.C.; Brooks, J.B. Gas-liquid chromatography-frequency pulse-modulated electron-capture detection in the diagnosis of infectious diseases. J. Chromatogr. B Biomed. Sci. Appl. 1983, 274, 1-25. [CrossRef]

99. Zhu, J.; Bean, H.D.; Kuo, Y.-M.; Hill, J.E. Fast Detection of Volatile Organic Compounds from Bacterial Cultures by Secondary Electrospray Ionization-Mass Spectrometry. J. Clin. Microbiol. 2010, 48, 4426-4431. [CrossRef]

100. Jünger, M.; Vautz, W.; Kuhns, M.; Hofmann, L.; Ulbricht, S.; Baumbach, J.I.; Quintel, M.; Perl, T. Ion mobility spectrometry for microbial volatile organic compounds: A new identification tool for human pathogenic bacteria. Appl. Microbiol. Biotechnol. 2012, 93, 2603-2614. [CrossRef] [PubMed]

101. Tavakkol, A.; Drucker, D.B. Gas chromatographic analysis of bacterial amines as their free bases. J. Chromatogr. B Biomed. Sci. Appl. 1983, 274, 37-44. [CrossRef] 
102. Labows, J.N.; McGinley, K.J.; Webster, G.F.; Leyden, J.J. Headspace Analysis of Volatile Metabolites of Pseudomonas Aeruginosa and Related Species by Gas Chromatography-Mass Spectrometry. J. Clin. Microbiol. 1980, 12, 521-526. [CrossRef]

103. Preti, G.; Thaler, E.; Hanson, C.W.; Troy, M.; Eades, J.; Gelperin, A. Volatile compounds characteristic of sinus-related bacteria and infected sinus mucus: Analysis by solid-phase microextraction and gas chromatography-mass spectrometry. J. Chromatogr. B 2009, 877, 2011-2018. [CrossRef]

104. Boots, A.W.; Smolinska, A.; Van Berkel, J.J.B.N.; Fijten, R.R.R.; Stobberingh, E.E.; Boumans, M.L.L.; Moonen, E.J.; Wouters, E.F.M.; Dallinga, J.W.; Van Schooten, F.J. Identification of microorganisms based on headspace analysis of volatile organic compounds by gas chromatography-mass spectrometry. J. Breath Res. 2014, 8, 027106. [CrossRef]

105. Kuzma, J.; Nemecek-Marshall, M.; Pollock, W.H.; Fall, R. Bacteria produce the volatile hydrocarbon isoprene. Curr. Microbiol. 1995, 30, 97-103. [CrossRef] [PubMed]

106. Filipiak, W.; Sponring, A.; Baur, M.; Filipiak, A.; Ager, C.; Wiesenhofer, H.; Nagl, M.; Troppmair, J.; Amann, A. Molecular analysis of volatile metabolites released specifically by staphylococcus aureus and pseudomonas aeruginosa. BMC Microbiol. 2012, 12, 113. [CrossRef] [PubMed]

107. Schöller, C.; Molin, S.; Wilkins, K. Volatile metabolites from some gram-negative bacteria. Chemosphere 1997, 35, 1487-1495. [CrossRef]

108. Maddula, S.; Blank, L.M.; Schmid, A.; Baumbach, J.I. Detection of volatile metabolites of Escherichia coli by multi capillary column coupled ion mobility spectrometry. Anal. Bioanal. Chem. 2009, 394, 791-800. [CrossRef]

109. Bunge, M.; Araghipour, N.; Mikoviny, T.; Dunkl, J.; Schnitzhofer, R.; Hansel, A.; Schinner, F.; Wisthaler, A.; Margesin, R.; Märk, T.D. On-Line Monitoring of Microbial Volatile Metabolites by Proton Transfer Reaction-Mass Spectrometry. Appl. Environ. Microbiol. 2008, 74, 2179-2186. [CrossRef]

110. Hamilton-Kemp, T.; Newman, M.; Collins, R.; Elgaali, H.; Yu, K.; Archbold, D. Production of the Long-Chain Alcohols Octanol, Decanol, and Dodecanol by Escherichia coli. Curr. Microbiol. 2005, 51, 82-86. [CrossRef]

111. Cox, C.D.; Parker, J. Use of 2-aminoacetophenone Production in Identification of Pseudomonas Aeruginosa. J. Clin. Microbiol. 1979, 9, 479-484.

112. Carroll, W.; Lenney, W.; Wang, T.; Španěl, P.; Alcock, A.; Smith, D. Detection of volatile compounds emitted by Pseudomonas aeruginosa using selected ion flow tube mass spectrometry. Pediatr. Pulmonol. 2005, 39, 452-456. [CrossRef]

113. Allardyce, R.A.; Hill, A.L.; Murdoch, D.R. The rapid evaluation of bacterial growth and antibiotic susceptibility in blood cultures by selected ion flow tube mass spectrometry. Diagn. Microbiol. Infect. Dis. 2006, 55, 255-261. [CrossRef]

114. Allardyce, R.A.; Langford, V.S.; Hill, A.L.; Murdoch, D.R. Detection of volatile metabolites produced by bacterial growth in blood culture media by selected ion flow tube mass spectrometry (SIFT-MS). J. Microbiol. Methods 2006, 65, 361-365. [CrossRef]

115. Scotter, J.M.; Allardyce, R.A.; Langford, V.S.; Hill, A.; Murdoch, D.R. The rapid evaluation of bacterial growth in blood cultures by selected ion flow tube-mass spectrometry (SIFT-MS) and comparison with the BacT/ALERT automated blood culture system. J. Microbiol. Methods 2006, 65, 628-631. [CrossRef]

116. Scott-Thomas, A.J.; Syhre, M.; Pattemore, P.K.; Epton, M.; Laing, R.; Pearson, J.; Chambers, S.T. 2-Aminoacetophenone as a potential breath biomarker for Pseudomonas aeruginosa in the cystic fibrosis lung. BMC Pulm. Med. 2010, 10, 56. [CrossRef] [PubMed]

117. Lawal, O.; Muhamadali, H.; Ahmed, W.M.; White, I.R.; Nijsen, T.M.E.; Goodacre, R.; Fowler, S.J. On behalf of the BreathDx Consortium. Headspace volatile organic compounds from bacteria implicated in ventilator-associated pneumonia analysed by TD-GC/MS. J. Breath Res. 2018, 12, 026002. [CrossRef]

118. Drees, C.; Vautz, W.; Liedtke, S.; Rosin, C.; Althoff, K.; Lippmann, M.; Zimmermann, S.; Legler, T.J.; Yildiz, D.; Perl, T.; et al. GC-IMS headspace analyses allow early recognition of bacterial growth and rapid pathogen differentiation in standard blood cultures. Appl. Microbiol. Biotechnol. 2019, 103, 9091-9101. [CrossRef] [PubMed]

119. Julák, J.; Stránská, E.; Rosová, V.; Geppert, H.; Španěl, P.; Smith, D. Bronchoalveolar lavage examined by solid phase microextraction, gas chromatography-mass spectrometry and selected ion flow tube mass spectrometry. J. Microbiol. Methods 2006, 65, 76-86. [CrossRef] [PubMed] 
120. Julák, J.; Stránská, E.; Procházková-Francisci, E.; Rosová, V. Blood Cultures Evaluation by Gas Chromatography of Volatile Fatty Acids. Med. Sci. Monit. 2000, 6, 605-610. [PubMed]

121. Dolch, M.E.; Janitza, S.; Boulesteix, A.-L.; Graßmann-Lichtenauer, C.; Praun, S.; Denzer, W.; Schelling, G.; Schubert, S. Gram-negative and -positive bacteria differentiation in blood culture samples by headspace volatile compound analysis. J. Biol. Res.-Thessalon. 2016, 23, 3. [CrossRef]

122. Aathithan, S.; Plant, J.C.; Chaudry, A.N.; French, G.L. Diagnosis of Bacteriuria by Detection of Volatile Organic Compounds in Urine Using an Automated Headspace Analyzer with Multiple Conducting Polymer Sensors. J. Clin. Microbiol. 2001, 39, 2590-2593. [CrossRef]

123. Pavlou, A.K.; Magan, N.; McNulty, C.; Jones, J.M.; Sharp, D.; Brown, J.; Turner, A.P.F. Use of an electronic nose system for diagnoses of urinary tract infections. Biosens. Bioelectron. 2002, 17, 893-899. [CrossRef]

124. Kodogiannis, V.S.; Lygouras, J.N.; Tarczynski, A.; Chowdrey, H.S. Artificial Odor Discrimination System Using Electronic Nose and Neural Networks for the Identification of Urinary Tract Infection. IEEE Trans. Inf. Technol. Biomed. 2008, 12, 707-713. [CrossRef]

125. Yates, J.W.T.; Chappell, M.J.; Gardner, J.W.; Dow, C.S.; Dowson, C.; Hamood, A.; Bolt, F.; Beeby, L. Data reduction in headspace analysis of blood and urine samples for robust bacterial identification. Comput. Methods Progr. Biomed. 2005, 79, 259-271. [CrossRef]

126. Sabeel, T.M.A.; CheHarun, F.K.; Eluwa, S.E.; Sabeel, S.M.A. Detection of volatile compounds in urine using an electronic nose instrument. In Proceedings of the 2013 International Conference on Computing, Electrical and Electronics Engineering (ICCEEE), Khartoum, Sudan, 26-28 August 2013; IEEE: Piscataway, NJ, USA, 2013; pp. 1-4.

127. Roine, A.; Saviauk, T.; Kumpulainen, P.; Karjalainen, M.; Tuokko, A.; Aittoniemi, J.; Vuento, R.; Lekkala, J.; Lehtimäki, T.; Tammela, T.L.; et al. Rapid and Accurate Detection of Urinary Pathogens by Mobile IMS-Based Electronic Nose: A Proof-of-Principle Study. PLoS ONE 2014, 9, e114279. [CrossRef] [PubMed]

128. Hayward, N.J. Head-space gas-Liquid chromatography for the rapid laboratory diagnosis of urinary tract infections caused by enterobacteria. J. Chromatogr. B Biomed. Sci. Appl. 1983, 274, 27-35. [CrossRef]

129. Gardner, J.W.; Yates, J.W.T.; Dow, C.S.; Chappell, M.J. Identification of bacterial pathogens using quadrupole mass spectrometer data and radial basis function neural networks. IEE Proc. Sci. Meas. Technol. 2005, 152, 97-102. [CrossRef]

130. Bruins, M.; Bos, A.; Petit, P.L.C.; Eadie, K.; Rog, A.; Bos, R.; van Ramshorst, G.H.; Van Belkum, A. Device-independent, real-time identification of bacterial pathogens with a metal oxide-based olfactory sensor. Eur. J. Clin. Microbiol. Infect. Dis. 2009, 28, 775-780. [CrossRef] [PubMed]

131. Neale, R.; Berman, D. The Long Read: We Must do Better for UTI Patients. Available online: https: //longitudeprize.org/blog-post/long-read-we-must-do-better-uti-patients (accessed on 8 June 2020).

132. Drabińska, N.; Jarocka-Cyrta, E.; Ratcliffe, N.; Krupa-Kozak, U. The Profile of Urinary Headspace Volatile Organic Compounds After 12-Week Intake of Oligofructose-Enriched Inulin by Children and Adolescents with Celiac Disease on a Gluten-Free Diet: Results of a Pilot, Randomized, Placebo-Controlled Clinical Trial. Molecules 2019, 24, 1341. [CrossRef] [PubMed]

133. Queralto, N.; Berliner, A.N.; Goldsmith, B.; Martino, R.; Rhodes, P.; Lim, S.H. Detecting cancer by breath volatile organic compound analysis: A review of array-based sensors. J. Breath Res. 2014, 8, 027112. [CrossRef]

134. Aggio, R.B.M.; Mayor, A.; Coyle, S.; Reade, S.; Khalid, T.; Ratcliffe, N.M.; Probert, C.S.J. Freeze-drying: An alternative method for the analysis of volatile organic compounds in the headspace of urine samples using solid phase micro-extraction coupled to gas chromatography - mass spectrometry. Chem. Cent. J. 2016, 10, 9. [CrossRef]

135. Kouri, T.; Fogazzi, G.; Gant, V.; Hallander, H.; Hofmann, W.; Guder, W.G. European Urinalysis Guidelines. Scand. J. Clin. Lab. Investig. 2000, 60, 1-96. [CrossRef]

136. Pernille, H.; Lars, B.; Marjukka, M.; Volkert, S.; Anne, H. Sampling of urine for diagnosing urinary tract infection in general practice-First-void or mid-stream urine? Scand. J. Prim. Health Care 2019, 37, 113-119. [CrossRef]

137. Delanghe, J.; Speeckaert, M. Preanalytical requirements of urinalysis. Biochem. Medica 2014, 89-104. [CrossRef] [PubMed]

138. Jobu, K.; Sun, C.; Yoshioka, S.; Yokota, J.; Onogawa, M.; Kawada, C.; Inoue, K.; Shuin, T.; Sendo, T.; Miyamura, M. Metabolomics Study on the Biochemical Profiles of Odor Elements in Urine of Human with Bladder Cancer. Biol. Pharm. Bull. 2012, 35, 639-642. [CrossRef] 
139. Rist, M.; Muhle-Goll, C.; Görling, B.; Bub, A.; Heissler, S.; Watzl, B.; Luy, B. Influence of Freezing and Storage Procedure on Human Urine Samples in NMR-Based Metabolomics. Metabolites 2013, 3, 243-258. [CrossRef] [PubMed]

140. Esfahani, S.; Sagar, N.; Kyrou, I.; Mozdiak, E.; O’Connell, N.; Nwokolo, C.; Bardhan, K.; Arasaradnam, R.; Covington, J. Variation in Gas and Volatile Compound Emissions from Human Urine as It Ages, Measured by an Electronic Nose. Biosensors 2016, 6, 4. [CrossRef] [PubMed]

141. Silva, C.L.; Passos, M.; Câmara, J.S. Investigation of urinary volatile organic metabolites as potential cancer biomarkers by solid-phase microextraction in combination with gas chromatography-mass spectrometry. Br. J. Cancer 2011, 105, 1894-1904. [CrossRef] [PubMed]

142. Netto, D.C.; Reis, R.M.; Mendes, C.B.; Gomes, P.C.F.L.; Martins, I.; Siqueira, M.E.P.B. Headspace solid-phase microextraction procedure for gas-chromatography analysis of toluene in urine. J. Braz. Chem. Soc. 2008, 19, 1201-1206. [CrossRef]

143. Robards, K.; Haddad, P.R.; Jackson, P.E. Headspace gas chromatography. In Principles and Practice of Modern Chromatographic Methods; Elsevier: Amsterdam, The Netherlands, 2004; pp. 75-177, ISBN 978-0-08-057178-2.

144. Heers, H.; Gut, J.M.; Hegele, A.; Hofman, R.; Boeselt, T.; Hattesohl, A.; Koczulla, A.R. Non-invasive Detection of Bladder Tumors Through Volatile Organic Compounds: A Pilot Study with an Electronic Nose. Anticancer Res. 2018, 38, 833-837.

145. Sakura, N.; Nishimura, S.; Fujita, N.; Namera, A.; Yashiki, M.; Kojima, T. Determination of acrolein in human urine by headspace gas chromatography and mass spectrometry. J. Chromatogr. B Biomed. Sci. Appl. 1998, 719, 209-212. [CrossRef]

146. Oliveira, D.P.D.; Siqueira, M.E.P.B.D. A simple and rapid method for urinary acetone analysis by headspace/gas chromatography. Quim. Nova 2007, 30, 1362-1364. [CrossRef]

147. Bosch, S.; El Manouni el Hassani, S.; Covington, J.A.; Wicaksono, A.N.; Bomers, M.K.; Benninga, M.A.; Mulder, C.J.J.; De Boer, N.K.H.; De Meij, T.G.J. Optimized Sampling Conditions for Fecal Volatile Organic Compound Analysis by Means of Field Asymmetric Ion Mobility Spectrometry. Anal. Chem. 2018, 90, 7972-7981. [CrossRef]

148. Tiele, A.; Wicaksono, A.; Ayyala, S.K.; Covington, J.A. Development of a Compact, IoT-Enabled Electronic Nose for Breath Analysis. Electronics 2020, 9, 84. [CrossRef]

149. Hu, W.; Wan, L.; Jian, Y.; Ren, C.; Jin, K.; Su, X.; Bai, X.; Haick, H.; Yao, M.; Wu, W. Electronic Noses: From Advanced Materials to Sensors Aided with Data Processing. Adv. Mater. Technol. 2018, 1800488. [CrossRef]

150. Mochalski, P.; Ruzsanyi, V.; Wiesenhofer, H.; Mayhew, C.A. Instrumental sensing of trace volatiles-A new promising tool for detecting the presence of entrapped or hidden people. J. Breath Res. 2018, 12, 027107. [CrossRef]

151. Schieweck, A.; Gunschera, J.; Varol, D.; Salthammer, T. Analytical procedure for the determination of very volatile organic compounds (C3-C6) in indoor air. Anal. Bioanal. Chem. 2018, 410, 3171-3183. [CrossRef] [PubMed]

152. Palma, S.I.C.J.; Traguedo, A.P.; Porteira, A.R.; Frias, M.J.; Gamboa, H.; Roque, A.C.A. Machine learning for the meta-analyses of microbial pathogens' volatile signatures. Sci. Rep. 2018, 8, 3360. [CrossRef] [PubMed]

153. Wang, C.-Y.; Cogswell, M.E.; Loria, C.M.; Chen, T.-C.; Pfeiffer, C.M.; Swanson, C.A.; Caldwell, K.L.; Perrine, C.G.; Carriquiry, A.L.; Liu, K.; et al. Urinary Excretion of Sodium, Potassium, and Chloride, but Not Iodine, Varies by Timing of Collection in a 24-Hour Calibration Study. J. Nutr. 2013, 143, 1276-1282. [CrossRef]

154. Slupsky, C.M.; Rankin, K.N.; Wagner, J.; Fu, H.; Chang, D.; Weljie, A.M.; Saude, E.J.; Lix, B.; Adamko, D.J.; Shah, S.; et al. Investigations of the Effects of Gender, Diurnal Variation, and Age in Human Urinary Metabolomic Profiles. Anal. Chem. 2007, 79, 6995-7004. [CrossRef]

155. Lenz, E.M.; Bright, J.; Wilson, I.D.; Hughes, A.; Morrisson, J.; Lindberg, H.; Lockton, A. Metabonomics, dietary influences and cultural differences: A $1 \mathrm{H}$ NMR-based study of urine samples obtained from healthy British and Swedish subjects. J. Pharm. Biomed. Anal. 2004, 36, 841-849. [CrossRef]

156. Perrier, E.; Rondeau, P.; Poupin, M.; Le Bellego, L.; Armstrong, L.E.; Lang, F.; Stookey, J.; Tack, I.; Vergne, S.; Klein, A. Relation between urinary hydration biomarkers and total fluid intake in healthy adults. Eur. J. Clin. Nutr. 2013, 67, 939-943. [CrossRef] 
157. Gradišek, A.; Van Midden, M.; Koterle, M.; Prezelj, V.; Strle, D.; Štefane, B.; Brodnik, H.; Trifkovič, M.; Kvasić, I.; Zupanič, E.; et al. Improving the Chemical Selectivity of an Electronic Nose to TNT, DNT and RDX Using Machine Learning. Sensors 2019, 19, 5207. [CrossRef]

158. Farraia, M.V.; Cavaleiro Rufo, J.; Paciência, I.; Mendes, F.; Delgado, L.; Moreira, A. The electronic nose technology in clinical diagnosis: A systematic review. Porto Biomed. J. 2019, 4, e42. [CrossRef] [PubMed]

159. Tambyah, P.A. Catheter-associated urinary tract infections: Diagnosis and prophylaxis. Int. J. Antimicrob. Agents 2004, 24, 44-48. [CrossRef] [PubMed]

160. Loh, K.Y.; Sivalingam, N. Urinary Tract Infections in Pregnancy. Malays. Fam. Physician 2007, 2, 54-57. [PubMed]

(C) 2020 by the authors. Licensee MDPI, Basel, Switzerland. This article is an open access article distributed under the terms and conditions of the Creative Commons Attribution (CC BY) license (http://creativecommons.org/licenses/by/4.0/). 